\title{
Final Report of Significance Testing at Site 41EP880 on Artcraft Road El Paso County, Texas
}

Christine G. Ward

Barbara J. Hickman

Follow this and additional works at: https://scholarworks.sfasu.edu/ita

Part of the American Material Culture Commons, Archaeological Anthropology Commons, Environmental Studies Commons, Other American Studies Commons, Other Arts and Humanities Commons, Other History of Art, Architecture, and Archaeology Commons, and the United States History Commons

Tell us how this article helped you.

This Article is brought to you for free and open access by the Center for Regional Heritage Research at SFA ScholarWorks. It has been accepted for inclusion in Index of Texas Archaeology: Open Access Gray Literature from the Lone Star State by an authorized editor of SFA ScholarWorks. For more information, please contact cdsscholarworks@sfasu.edu. 


\section{Final Report of Significance Testing at Site 41EP880 on Artcraft Road El Paso County, Texas}

\section{Licensing Statement}

This is a work produced for the Texas Department of Transportation (TxDOT) by the report producer. TxDOT and the report producer jointly own all rights, title, and interest in and to all intellectual property developed under TXDOT's contract with the report producer. The report may be cited and brief passages from this publication may be reproduced without permission provided that credit is given to both TxDOT and the report producer. Permission to reprint an entire chapter, section, figures or tables must be obtained in advance from either the Supervisor of the Archeological Studies Branch, Environmental Affairs Division, Texas Department of Transportation, 125 East 11th Street, Austin, Texas, 78701 or from the report producer. 


\title{
Final Report of Significance Testing at Site 41EP880 \\ On Artcraft Road \\ El Paso County, Texas
}

\author{
By \\ Christine G. Ward \\ With \\ Barbara J Hickman
}

May 1997

\section{Environmental Affairs Division Texas Department of Transportation}





\begin{abstract}
Test excavations were undertaken at 41EP880 in northwest El Paso County, Texas in January of 1994 by archeologists from the Environmental Affairs Division of the Texas Department of Transportation. The site is located along the lower portion of an alluvial fan of the Franklin Mountains overlooking the Rio Grande Valley.

The project calls for an additional $18 \mathrm{~m}$ (60 ft.) of right-of-way in the vicinity of the archeological site, which extends both to the north and the south of the existing road. All additional right-of-way will be acquired from the northern side of Artcraft Road. Since the existing roadway cuts through the site, a large amount of disturbance is evident across the surface of the site. Testing, in the form of $1 \mathrm{~m}^{2}$ test units, backhoe trenches, shovel tests, and the cutting of two profiles, indicated that the disturbances are extensive and extend into the new right-of-way. The information garnered about the site indicates that the portion of site to be impacted by road construction is n ot eligible for listing on the National Register of Historic Places. Extensive disturbances have secondarily deposited much of the prehistoric occupational debris, leaving little in the way of intact subsurface deposits.
\end{abstract}




\section{ACKNOWLEDGMENTS}

Thanks go first to the El Paso District of the Texas Department of Transportation (TxDOT) for arranging a right-of-entry agreement with the landowners for permission to test the archeological site on their property. Judy Ramsey and Mary Telles-Goins, the El Paso District environmental coordinators, solved many logistical problems for us, as well. Several people from the El Paso District also acted as crew members during the site testing. The volunteers included Allison Perez, Aldo Cardona, Ismael Hernandez, Art Gutierrez, Hector Chanez, Tom Hughes, and Rebecca Grado.

Paul Maslyk and William J. Weaver accompanied Christine Ward to El Paso to test the site and also contributed suggestions and opinions following their return to Austin. Dr. David G. Robinson of the Texas Archeological Research Laboratory (TARL) identified the ceramic sherds that were recovered at the site. Glenn Goode and Carlos Swonke of the TxDOT Environmental Affairs Division (ENV) helped with the identification of the lithics and the identification of the lithic raw materials, respectively. Lastly, my thanks go to Dr. David Carmichael and Dr. John Peterson of the University of Texas at El Paso for advice and suggestions regarding 41EP880 and the general archeology of the El Paso vicinity. 


\section{TABLE OF CONTENTS}

ABSTRACT $\ldots \ldots \ldots \ldots \ldots \ldots \ldots \ldots \ldots \ldots \ldots \ldots \ldots \ldots \ldots \ldots$ i

ACKNOWLEDGMENTS $\ldots \ldots \ldots \ldots \ldots \ldots \ldots \ldots \ldots$ iii

LIST OF FIGURES $\ldots \ldots \ldots \ldots \ldots \ldots \ldots \ldots \ldots \ldots \ldots$ vi

LISTOFTABLES $\ldots \ldots \ldots \ldots \ldots \ldots \ldots \ldots \ldots$ vii

INTRODUCTION $\ldots \ldots \ldots \ldots \ldots \ldots \ldots \ldots \ldots \ldots \ldots \ldots \ldots$

PROJECT DESCRIPTION $\ldots \ldots \ldots \ldots \ldots \ldots \ldots \ldots \ldots \ldots \ldots$

SITE DESCRIPTION $\ldots \ldots \ldots \ldots \ldots \ldots \ldots \ldots \ldots \ldots \ldots \ldots \ldots$

ENVIRONMENTAL SETTING OF THE SITE AREA $\ldots \ldots \ldots \ldots \ldots \ldots \ldots$

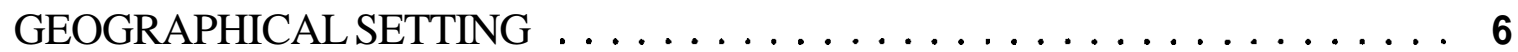

SOILS AND STRATIGRAPHY $\ldots \ldots \ldots \ldots \ldots \ldots \ldots \ldots \ldots$

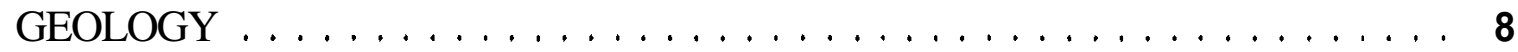

SURFACEWATER $\ldots \ldots \ldots \ldots \ldots \ldots \ldots \ldots \ldots \ldots \ldots \ldots$

ENVIRONMENTALZONES $\ldots \ldots \ldots \ldots \ldots \ldots \ldots \ldots \ldots$

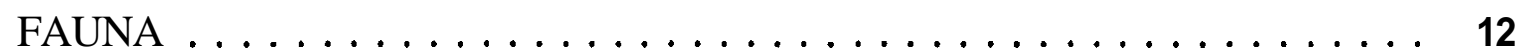

CULTURAL BACKGROUND $\ldots \ldots \ldots \ldots \ldots \ldots \ldots \ldots \ldots \ldots \ldots$

CHRONOLOGY ...................... 13

Paleoindian Period . . . . . . . . . . . . . . . . 13

Archaic Period ............................ 13

Formative Period . . . . . . . . . . . . . . . . . . . . . . 14

SITES ALONG THE WESTERN FLANKS OF THE FRANKLIN

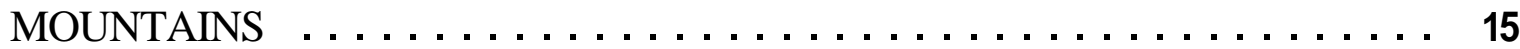

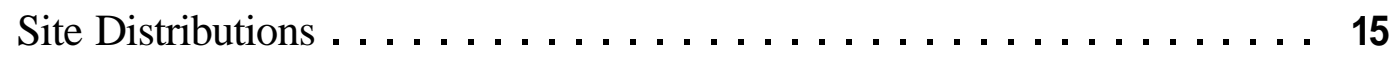

Lithic Raw Materials . . . . . . . . . . . . . . . . 16

FIELDMETHODS $\ldots \ldots \ldots \ldots \ldots \ldots \ldots \ldots \ldots \ldots \ldots \ldots \ldots \ldots$

RESULTS OF FIELD INVESTIGATIONS $\ldots \ldots \ldots \ldots \ldots \ldots \ldots \ldots \ldots \ldots$

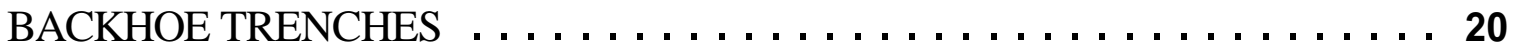

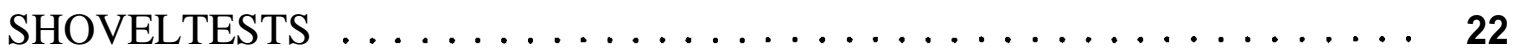

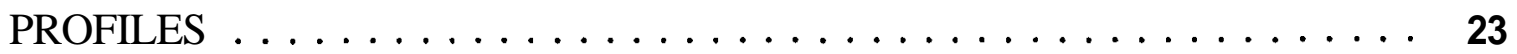

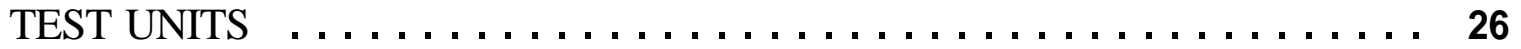




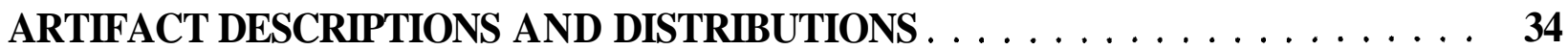

LITHIC ARTIFACTS $\ldots \ldots \ldots \ldots \ldots \ldots \ldots \ldots \ldots \ldots \ldots \ldots$

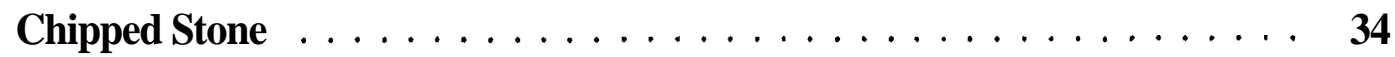

Unmodified Debitage $\ldots \ldots \ldots \ldots \ldots \ldots \ldots \ldots \ldots \ldots \ldots$

Edge-altered Debitage . . . . . . . . . . . . . . . . . . . . . 39

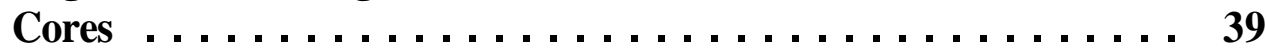

Projectile Points . . . . . . . . . . . . . . 39

Uniface ..................... 40

Ground and Pecked Stone $\ldots \ldots \ldots \ldots \ldots \ldots \ldots \ldots \ldots \ldots$

Hammerstones $\ldots \ldots \ldots \ldots \ldots \ldots \ldots \ldots \ldots \ldots \ldots \ldots \ldots$

CERAMICS $\ldots \ldots \ldots \ldots \ldots \ldots \ldots \ldots \ldots \ldots \ldots \ldots$

DISCUSSION $\ldots \ldots \ldots \ldots \ldots \ldots \ldots \ldots \ldots \ldots \ldots \ldots \ldots \ldots \ldots$

CONCLUSIONS AND RECOMMENDATIONS . . . . . . . . . . . . . . . . . . 49

REFERENCESCITED $\ldots \ldots \ldots \ldots \ldots \ldots \ldots \ldots \ldots \ldots \ldots \ldots \ldots \ldots, \mathbf{5 1}$ 


\section{LIST OF FIGURES}

Figure 1. Location map of 41EP880. El Paso County. Texas $\ldots \ldots \ldots \ldots \ldots . .2$

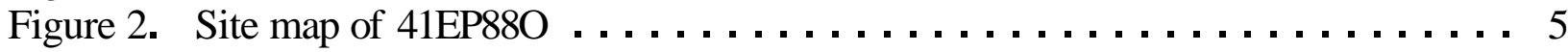

Figure 3. Topographic map of the site area $\ldots \ldots \ldots \ldots \ldots \ldots \ldots \ldots \ldots$

Figure 4. Map of the environmental zones along the western Franklin Mountains . . . 10

Figure 5. Site map of 41EP88O showing test unit. backhoe trench. and shovel test

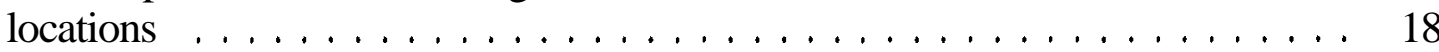

Figure 6. Profile drawn of the south wall at the eastern end of Backhoe Trench $2 \ldots 21$

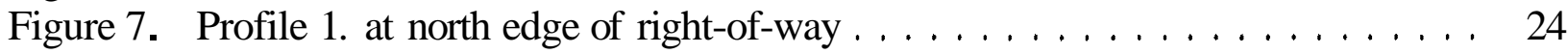

Figure 8. Profile 2. along south side of $\operatorname{road} \ldots \ldots \ldots \ldots \ldots \ldots \ldots \ldots \ldots \ldots$

Figure 9. Plan map of rock exposed in Level 3. Test Units 1. 6. and 7 . . . . . . . 27

Figure 10. Profile of the north wall of Test Unit 4 . . . . . . . . . . . . . . . . . . 29

Figure 11. Plan map of exposed rock on the surface of Test Unit $9 \ldots \ldots \ldots 33$

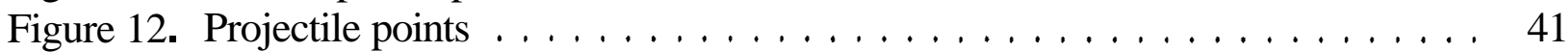

Figure 13. Large uniface recovered in TU 8. Level $7 \ldots \ldots \ldots \ldots \ldots$. . . . . . . . . 42

Figure 14. Ground stone recovered in Backhoe Trench 2 . . . . . . . . . . . . . . 43

Figure 15. Alma Plain ceramics collected from both surface and subsurface contexts . . 46

Figure 16. Jornada and El Paso Brown sherds from surface and subsurface contexts . . . 47 


\section{LIST OF TABLES}

Table 1. Intrusive historic artifacts collected at 41EP88O from subsurface contexts $\ldots .35$

Table 2. Provenience and identification of lithic artifacts $\ldots \ldots \ldots \ldots \ldots \ldots \ldots$

Table 3. Proveniences and identification of ceramics $\ldots \ldots \ldots \ldots \ldots \ldots \ldots$ 


\section{INTRODUCTION}

Significance testing of eligibility for listing on the National Register of Historic Places was undertaken at site 41EP880 in El Paso, Texas (Figure 1). The test excavation was accomplished between January 3 and 14, 1994 by archeologists from the Environmental Affairs Division (ENV) of the Texas Department of Transportation (TxDOT). This testing was prompted by the discovery of ceramics, ground stone, presumed burned rock, and lithic debris both in surface and subsurface contexts. The initial investigations were conducted in 1991 and 1992 during two routine surveys of the project area (Browning 1992; TxDOT 1992).

The proposed project calls for the extension, widening, and straightening of the existing Artcraft Road in northwest El Paso. After completion of the roadway improvement, Artcraft Road will serve as a connecting road from 1.H. 10 in Texas to a newly opened port-of-entry between the State of Chihuahua, Mexico and the town of Santa Teresa, New Mexico. This proposed route is approximately $19.2 \mathrm{~km}$ (12 mi.) long with an average width of $60 \mathrm{~m}(200 \mathrm{ft}$.); this corridor encompasses roughly 116 ha (291 acres).

Despite considerable disturbance on the surface of the site, it was nonetheless determined that, because of the potential for subsurface archeological deposits, the site might yet be eligible for listing on the National Register of Historic Places (NRHP). Ten test units, five backhoe trenches, eight shovel tests, and two profiles cut into sloped areas were dug on site during the testing operations. Between the various profiles and the recovered materials, it was determined that the site was extensively disturbed within the right-of-way, leaving little or no intact subsurface deposits. 
This Page Redacted Per THC Policy 


\section{PROJECT DESCRIPTION}

Site 41EP880 was identified during a survey of Artcraft Road in northwest El Paso, Texas in 1991-1992 (B rowning 1992). The A rtcraft Road construction project consists of a proposed six lane, controlled access roadway from the Santa Teresa border crossing in New Mexico south of the Texas boundary to I.H. 10 in El Paso, Texas. The project is approximately $19.2 \mathrm{~km}$ (11.6 milong. From the border crossing, the alignment follows the existing Santa Teresa B eltway, a paved temporary road. The alignment then intersects at-grade with A irport Road; roughly 800 $\mathrm{m}(0.5 \mathrm{mi}$.) north of Airport Road, the alignment turns east toward I.H .-10 and extends down the escarpment into the Rio Grande V alley for $3.2 \mathrm{~km}(2 \mathrm{mi}$.). At the base of the escarpment, the alignment meets N.M. 273 and then proceeds in an easterly direction across the Rio Grande V alley, intersecting with W estside D rive, U pper Valley Road, and Strahan Road. A fter crossing the Rio Grande, the route extends across the Santa Fe Railroad and State Highway 20 (D oniphan D rive), connecting at this point with the existing A rtcraft Road. A rtcraft continues in an easterly direction up onto the alluvial fan along the Franklin M ountains, where it currently intersects with I.H. 10.

A total of 11 archeological sites was located along the entire length of the survey. Ten of these sites lie in New M exico, and a single site lies within the Texas portion of the survey. The Texas site, 41EP880, was plotted on the 7.5' USGS Canutillo quadrangle topographic map on file at the Texas A rchaeological Research L aboratory (TARL) at an unknown time in the past and by an unknown party. No documentation of the site was apparently completed at that time. It was relocated during the Class II archeological and historic building survey of the A rtcraft Road project by archeologistsfrom Human Systems Research, Inc. of Tularosa, New M exico (B rowning 1992). At that time, a site record form was not completed though surface observations were made and recorded (Browning 1992:9). Later in 1992, an archeologistfrom TxD OT's Environmental A ffairs Division conducted an additional survey of the site area with the intent of properly recording the site and shovel testing for intact subsurface deposits (TxD OT 1992). In both of the survey reports, this site was recommended for further investigation.

At the time of each survey theproject right-of-way was not staked. Thus it was unknown how large a portion of the site might lie within the bounds of the proposed project. The site, however, was visible on both the north and south sides of the road; therefore, it was known that at least some of site was located within the right-of-way. It was also known that at least a portion of the site had previously been disturbed by the original construction of the roadway and routine roadway maintenance since that time.

The existing right-of-way for A rtcraft Road is variable but averages around $40 \mathrm{~m}$ (130 ft.). The proposed right-of-way will expand this to an average of $61 \mathrm{~m}(200 \mathrm{ft}$.). All additional rightof-way al ong this portion of the project will be taken from the northern side of the existing road. Within the bounds of the archeological site, the additional right-of-way consists of just 18 additional meters (60ft.) of property. A ccess was gained to this property through a right-of-entry agreement with the landowners coordinated by the TxDOT EI Paso District. 


\section{SITE DESCRIPTION}

The extent of site 41EP880 parallel to existing Artcraft Road is approximately $100 \mathrm{~m}$, based on the surface distribution of cultural debris (Figure 2). The subsurface deposits, however, are thought to be more narrowly distributed toward the eastern end, or upslope portion, of the area. Materials from the site appear to have been displaced downslope along Artcraft Road from the terrace edge due to road construction and associated maintenance activities.

The north-south extent of the site, perpendicular to the roadway, was originally recorded as $300 \mathrm{~m}$ across. Approximately $60 \mathrm{~m}$ of this distance is within the proposed right-of-way.

Within the right-of-way, the site is characterized only by surficial scatters of artifacts. No features are apparent, nor are concentrations of artifacts particularly obvious. Scattered artifacts collected from the surface include a reworked obsidian dart point, four brownware ceramic sherds, and a variety of lithic debris.

Outside the right-of-way, immediately to the north, several likely features are apparent on the surface. These include three dark, round or oval stains ( $<3 \mathrm{~m}$ diameter), and at least three large (2-3 m) concentrations of rock and lithic debris. Outside the right-of-way, in this same area, the topography of the landscapetill appears to retain some of its original character. The terrace edge is still intact in this area outside of the right-of-way.

At the far northeastern end of the site is a fence line which delineates the location of the Sahara Sportswear Factory. Previous impacts to the site include the cutting of two dirt roads, both on the upslope portion of the site. Throughout the site are numerous piles of recent trash, especially near the two dirt roads and the main paved road. Several distinct piles were noted on site (see Fig. 2). Additional disturbance was noted in the form of a borrow pit, located close to one of the dirt roads which runs northwestward through the site from Artcraft Road. The Sahara Sportswear property is disturbed within the fenced area, thus any evidence that the site extends beyond the fence line and onto the factory property was obliterated by the parking lot and structure. Another, less distinct dirt road parallels the fence line on the portion of the property which will be included within the new right-of-way. 


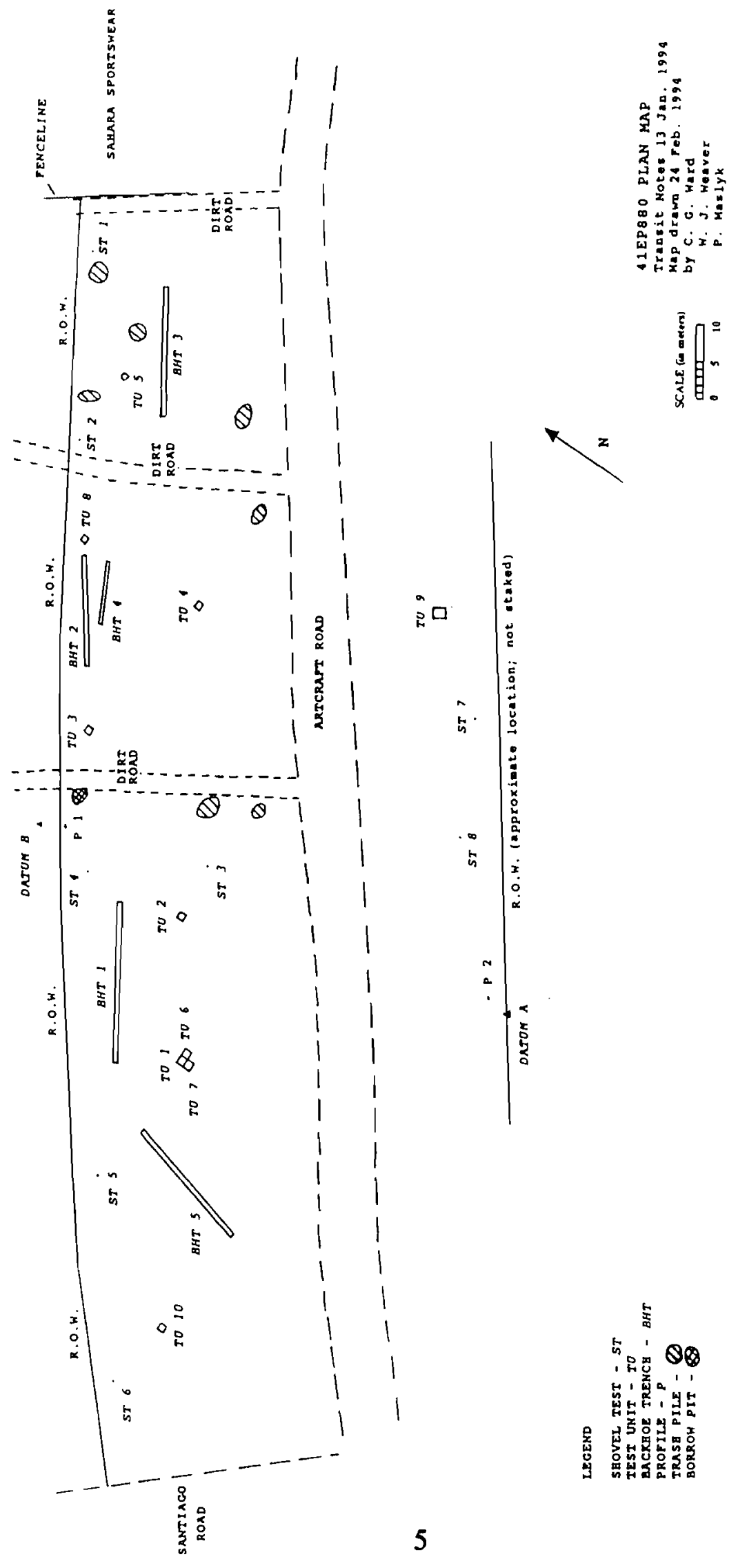

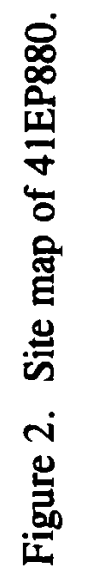




\section{ENVIRONMENTAL SETTING OF THE SITE AREA}

\section{GEOGRAPHICAL SETTING}

The El Paso area lies within the Mexican Highlands section of the Basin and Range province (Fenneman 1931). The Basin and Range province is "...distinguished by isolated, roughly parallel mountain ranges separated by desert basins, generally almost level" (Fenneman 1931:326). In El Paso, the Franklin Mountains represent the range, or horst, portion; the Mesilla Bolson to the west and the Hueco Bolson to the east represent the basin, or graben, portion of the landscape (Lovejoy 1980).

The site is located in the northwest portion of the city of El Paso, overlooking the Rio Grande floodplain between $1163.5 \mathrm{~m}$ and $1175.7 \mathrm{~m}$ elevation. It is situated on a terrace $18 \mathrm{~m}$ to $30 \mathrm{~m}$ above the floodplain, east of the river, just below the western foothills of the Franklin Mountains (Figure 3).

\section{SOILS AND STRATIGRAPHY}

The lower slopes and alluvial fans on the west side of the Franklin Mountains are dominated by the Delnorte-Canutioassociation of soils (Jaco 1971). The Rio Grande floodplain exhibits the Harkey-Glendale soil association. A narrow band of Bluepoint association soils is located between the lower slopes and alluvial fans and the Rio Grande floodplain. Bluepoint association ranges in width from less than $0.4 \mathrm{~km}(0.25 \mathrm{mi})$ to $2.41 \mathrm{~km}$ (1.5 mi). According to Jaco (1971:21) soils in the Bluepoint association are characterized by a "...pale brown, alkaline loamy fine sand to a depth of at least $60 \mathrm{in."} \mathrm{(1.52} \mathrm{m.).} \mathrm{Site} \mathrm{41EP880lies} \mathrm{within} \mathrm{one} \mathrm{of} \mathrm{these}$ localized bands of Bluepoint association soils.

The deposits within which the cultural debris lies is a homogenous light to medium brown sand with a few small gravel inclusions which is more than a meter thick. The cultural debris is concentrated in the uppermost $50 \mathrm{~cm}$ of these loamy sand deposits, though small flakes and scattered debris were recovered from all levels of some excavation units to the top of the underlying gravel deposits.

Underlying the site, at a depth of $1.0 \mathrm{~m}$ to roughly $1.3 \mathrm{~m}$, is a layer of gravels. These are $5-20 \mathrm{~cm}$ in size and all are coated with a rind of calcium carbonate deposits which have filtered through the soils and into the alluvial gravels. The gravel layer was not identified in all areas of the site; however, it is thought to underlie all areas. 
This Page Redacted Per THC Policy 


\section{GEOLOGY}

The Franklin M ountains areatilted fault block range with the dip slope facing to the west (Lovejoy1980). The site lies along the foothills of that slope. Those layers exposed on the western slopes of the mountains include the EI Paso LimestoneFormation and, in areas where this layer haseroded, the 'Thunderbird Rhyolite formation. Overlying the EI Paso Limestone, and still visible as a band only on the eastern slopes, is the M ontoya Dolomite. On the western slopes of the mountains, this layer has, for the most part, eroded away (Lovejoy 1980). Both the El Paso Limestone and the M ontoya Dolomite are chert-bearing limestone formations(Sellards, et al. 1932). Other formations in the mountains which provided lithic raw material for the inhabitants of the site include the Thunderbird Rhyolite formation which is exposed on the west side of the mountains, and sedimentary siltstonesand sandstones. In nearby arroyos and amongst the gravels underlying the site are quartite and other cobbles which may also have been collected for use. In the river valley, small pebbles of obsidian are occasionally found; use of pebble obsidian by the prehistoric inhabitants of the area is documented archeologically.

Below the western slopes of the mountains is a fault zone, visible as a line of denser vegetation running north-south. This fault zone separates the Franklin Mountain Block from the Mesilla Bolson Block. The Mesilla Bolson, toward the southern end of which the site is located, extends from Las Cruces, New Mexico to northwestern El Paso. It is bordered on the west by the Sierra de las Uvas and the Portrillo mountains and on the east by the Organ and Franklin mountains. Until mid-Pleistocene times, the bolson was closed, thus the basin was filled with debris from the mountains, the ancestral Rio Grande, and the lacustrine deposits of Lake Cabeza de $\mathrm{V}$ a c a At the time the ancestral river emptied in the immediate area into the large lake. Over $1000 \mathrm{~m}$ of this fill are present in the bolson (Holliday 1983). Since the Rio Grande eventually cut through the end of the lake, providing through drainage to the Gulf of Mexico, the river has entrenched $90 \mathrm{~m}$ into the floor of the basin. The Mesilla Valley was formed by the entrenchment, and the present floor of the Mesilla Bolson is the La Mesa surface, a level, uninterrupted plain above the valley. Four late Quaternary surfaces, all post-dating the entrenchment of the river, have been identified along the river in the bolson (Holliday 1983); consistent with Holliday's (1983) depositional stratigraphic units, site 41EP880 appears to lie on the edge of the valley, atop the Picacho-Gold Hill Quaternary surface.

\section{SURFACE WATER}

The Rio Grande, $1.0 \mathrm{~km}$ to the west of the site, is presently the only permanent source of water in the area. Such has not always been the case; prior to the 1916 construction of Elephant Butte Dam upstream, the Rio Grande went through both periodic flooding and desiccation. B ecause the river's course and flow have been controlled by the construction of the dam, current studies on the river's flow through the valley are not available. O'Laughlin (1980: 12), however, 
has reconstructed some information about the river's activity based on historical reports; the information below has been taken primarily from that text.

Though the river's channel is currently located toward the eastern side of the floodplain, historically it was known to change course from one side of the floodplain to the other on an unpredictable basis. The heaviest flow for the year was in the spring, when both floods and coursechanges were considered likely. However, after J une, when radically less rainfall would occur, the river was entirely dry in the years $1879,1891,1894$, and 1896. Its unpredictability as a consistent sourceof water, and the unpredictability of its location within its floodplain would certainly have been important factors in the locations of habitation sites along its banks.

In addition to the Rio Grande, two relatively large arroyos are located nearby the site. One is $0.4 \mathrm{~km}$ to the north and runs in a northwesterly direction toward a junction with another large arroyo $1.0 \mathrm{kmnorth}$ of the site. The other is located $0.8 \mathrm{kmto}$ the south of the site and runs directlywestward toward the river. N either of these arroyos carries water on a regular basis; their primary source of water is surface runoff after heavy rains, and, even then, only on a temporary basis.

\section{ENVIRONMENTAL ZONES}

O'Laughlin (1980:14) identified six environmental zones in the vicinity of the nearby Keystone Dam project "...on the basis of land form, substrate, and clearly visible patterns in the distribution of plant species" (Figure 4). Based on paleoenvironmental studies for the area, these plant distributions are thought to broadly reflect those that were present at least from midHolocene times (O'Laughlin 1980). Unless otherwise stated, the discussion below of the environmental zones has been taken from O'Laughlin (1980).

The Mountain zone is located entirely in the Franklin Mountains above 1460 m elevation. The slopes are quite steep on the west side of the mountains and are presently without enough vegetation to prevent erosion of the shallow soils. Only a single food item of those currently available in this zone was restricted entirely to this zone. Acorns have been found in prehistoric context at one site in the El Paso area (Brook 1966). Other available resources, which are also present in some of the other zones include sotol, yucca, lechuguilla, prickly pear, mesquite, and a variety of grasses.

The Upper Bajada zone lies along the west alluvial slope at the foot of the mountains. The soils are deeper than those in the mountain zone but are still gravelly to rocky in content. The plants available in this zone which may have been utilized as food sources by the prehistoric inhabitants are similar to those listed above and include sotol, yucca, lechuguilla, prickly pear, and, again, even though not commonly present today, a variety of grasses. 


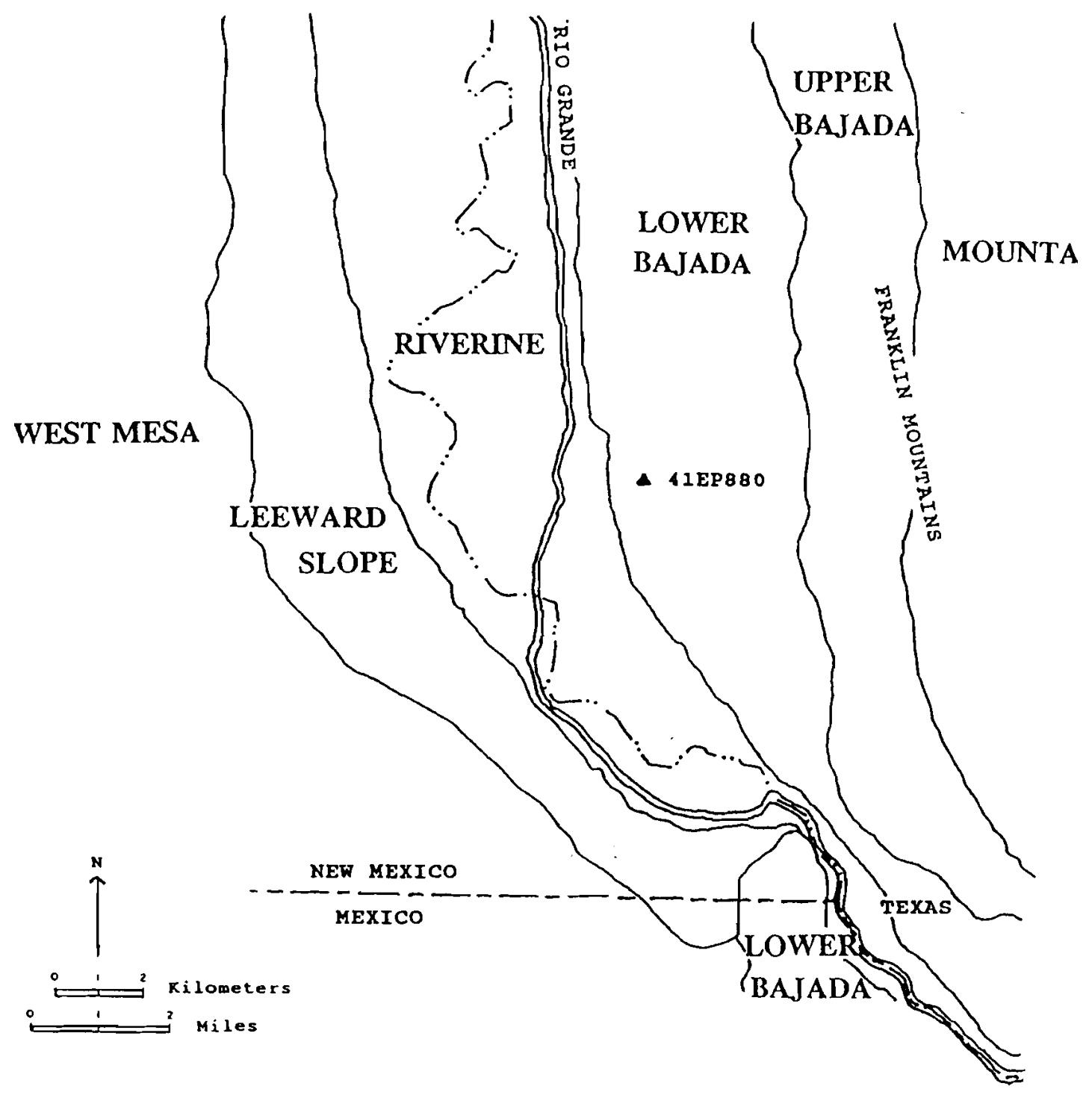

Figure 4. Map of the Environmental Zones along the western Franklin Mountains (adapted from 0 'L aughlin 1980:15). 
The Lower Bajada zone includes the lower elevations of the west alluvial slope of the mountains; this includes the 41EP880 site area. The slope is less steep than in either of the previous zones and the soils are deeper and less rocky. Yucca, prickly pear, grass seeds, and mesquite areall available as food sources but none are found in abundance except at the far western edges of the zone where some during has occurred. Here, mesquite and soap-tree yucca are found in relative profusion, making their collection as food resources in prehistoric times more likely. A cacia seeds would have been available in the L ower B ajada area as well.

The Riverine zone, which includes the floodplain, is the primary zone that has been extremely altered in historic times. Aswas noted earlier, the flooding and meandering of the river channel was unpredictable, but such processes undoubtedly occurred prehistorically. Changes in the river's flow and course would have affected the usefulness and availability of plant resources located in this zone. Some of the most useful food resources that were likely available prehistorically near the river include tornillo, mesquite, wolfberry, cattail, amaranth, goosefoot, purslane, and dock.

On the west side of the river, along the ridges and shallow drainages between the river and the La M esa surface, is the Leeward Slope zone. Eolian soils dominate the area; thus, erosion and during arecommon occurrences. A gain, as in the dunal areas of the Lower Bajada zone, the most important food resources in this area were the mesquiteand soap-treeyucca. Grasses also would have been available but not as abundantly as in other zones.

The W est M esa zone is located further west from the river valley, and includes the large, relatively level upland plain. Sandy soils and the formation of dunes characterize the plain; the dunes generally develop around mesquite, separated by barren interdunal areas. M esquite and the soap-tree yucca again would be the plants most utilized as food resources by the prehistoric peoples in this zone.

Seasonally, these plant resources differ somewhat, thus making some environmental zones more useful during certain periods than others. Other than the oak, which is thought to have played an extremely minor role in the prehistoric diet in the area (O'Laughlin 1980: 16), the plants available in the Mountain zone would have been most abundant during the spring (sotol, yucca, lechuguilla) and the fall (prickly pear, mesquite). Those plants in the Upper Bajada zone reflect this same type of probable exploitation pattern (sotol, yucca, and lechuguilla in the spring; prickly pear in the fall).

In the Lower Bajada zone, other than the mesquite and soap-tree yucca found in localized profusion near dunal areas, few of the plant resources could be found in large enough quantities to justify identification as truly collectible resources. The mesquite would have been most available in the fall and the yucca in the late spring or early summer. Likely, any resources in this zone would have been collected only by gatherers en route to one of the adjacent environmental zones.

The riverine resources could have provided food almost year round; their occurrences would have been common enough to justify a fair amount of time spent in collecting. Wolfberry, amaranth, goo sefoot, purslane, and dock were most available in spring and summer. Tornillo and mesquite were both available in the fall; however, of the two, tornillo would have been more highly preferred due to its high sugar content. Different parts of the cattail were available at varying times of the year, making this resource highly usable due to its year-round availability. 
In the Leeward Slope zone, mesquite, which was only available in very localized amounts in other zones, is extremely common and available in the fall. Yucca, though most available in spring (the crowns), could also have been exploited year-round. This same pattern of availability applies to the West Mesa zone (0'Laughlin 1980).

\section{FAUNA}

A number of primarily small mammals are found throughout the area, including cottontail, jack rabbit, squirrels, rats, mice, pronghorn antelope, and deer. Regarding the prehistoric exploitation of the fauna, O'Laughlin (1977) has detailed three broad hunting patterns for the area based on faunal remains recovered in archeological context.

The pursuit of deer characterizes the Highland hunting pattern; since deer aggregate in winter and disperse in summer, a winter pattern would have been expected for hunting in the highlands. The lowland pattern, found in the U pper and Lower Bajada zones, the Leeward Slope, and the West Mesa, is characterized by hunting jack rabbit, cottontail, and pronghorn. The riverine pattern includes the hunting of those animals found among the lowland pattern but also includes fish, turtle and water fowl. Overall, jack rabbit and cottontail vary inversely to one another dependent upon the density of ground cover. Both of these would be most available in the spring and summer. Deer, due to winter aggregation, are most easily hunted during this season; their distribution is broad and encompasses all zones (0'Laughlin 1977). 


\section{CULTURAL BACKGROUND}

\section{CHRONOLOGY}

The chronological framework employed in the report broadly follows the scheme that is commonly used in the El Paso area. The chronology includes three general periods - Paleoindian, Archaic, and Formative. These periods are discussed in far greater detail by others (Whalen 1978; O'Laughlin 1980; Carmichael 1985) than the brief discussion permitted here.

\section{Paleoindian Period}

The Paleoindian Period is generally recognized as a period of big-game hunting from roughly 11,000 to 8,000 years ago (B.P.). The climate was wetter and cooler during this period than at present; thus, large savanna or open woodland areas probably dominated the landscape. With the wetter and cooler conditions, more permanent streams and lakes were also present, thus a wider variety of larger game animals was available. Paleoindian lifeways are typically associated with the hunting of large game animals, such as mammoth and bison, and a highly mobile pattern of human behavior.

The earliest part of this period, as represented by the very distinctive Clovis projectile point, has been poorly defined for the immediate area of south-central New Mexico and El Paso (Carmichael 1985), and no dates are available for the immediate area. Folsom projectile points, representing the middle of the Paleoindian sequence, have been identified very nearby El Paso in southern New Mexico (Quimby and Brook 1967; Carmichael 1983), and in the Hueco Bolson east of El Paso (Brook 1968). Indicated lifeways during this time, dated elsewhere to roughly 11,500 to 10,000 years B.P., again include a highly mobile hunting and gathering strategy (Carmichael 1985).

From 10,500 to 8,000 years B.P., a later tradition has been identified. A site identified as belonging to this tradition was documented in southeast El Paso (Kaufman 1984). The setting is similar to that which might have been recorded for Folsom sites outside the immediate area, suggesting a continuum of site locales into this later period (Carmichael 1985).

\section{Archaic Period}

This period is generally dated to between 8,000 and 2,000 years B.P. (Carmichael 1985; O'Laughlin 1980; Whalen 1978). The Archaic is characterized environmentally as a period of warmer and more arid conditions, with present conditions established between 8,000 and 4,000 years B.P. Scheduling of exploitation patterns became key to the subsistence and settlement 
mobility strategies of the prehistoric populations due to "...increased spatial and seasonal variability in key resources" (Carmichael 1985: 11).

Increased variability in projectile point typologies, a greater emphasis on gathering of plant resources, and a wider range of topographic settings for site locations are all indicated. The first of these may reflect an increase in regionalization, and the second and third may reflect the exploitation of a broader spectrum of resources (Carmichael 1985). An increase in population in the area is certainly indicated. The domestication of some plants was introduced and the construction of pithouse dwellings may also have begun toward the end of this extensive period (O'Laughlin 1980).

\section{Formative Period}

The EI Paso area lies within that region originally defined by Lehmer (1948) as the J ornada B ranch of the Mogollon. The sequence that was proposed is still, for the most part, in use today with a few minor exceptions. First, Lehmer (1948) proposed a Hueco phase as a precursor to the ceramic phases. Somewhat similar to the Late A rchaic; it is no longer used due to a great deal of confusion over its definition. Secondly, since the original sequence was proposed, the dates of the first ceramics, one of the hallmarks of the Formative period, have been pushed back by almost 1,000 years. Initially, Lehmer's (1948) Formative period began with ceramics and pithouses at A.D.900. Now, pithouses have been dated to roughly A.D. 400 and the earliest ceramics first appeared aroundA.D. 1 (W halen 1978). The three phases into which the Formative period is split, corrected for the temporal differences from the original, are the M esilla phase (A.D. 1-1100). the D ona A na phase (A.D. 1100-1200), and theEI Paso phase (A.D. 1200-1400) according to Carmichael(1985). Whalen (1985) prefers to separatethe M esilla phase into the Early Pithouse period (A.D. 1-600) and Late Pithouse period (A.D. 600-1100). Next is the Transitional Pueblo period (A.D. 1100-1200), followed by the Early (A.D. 1200-1300) and Late (A.D. 1300-1400) Pueblo periods. The more traditional three phase sequence as defined by Lehmer (1948) and updated by various others (Whalen 1978; Carmichael 1985) is discussed briefly below.

TheM esilla phase begins with the addition of ceramics to the artifact assemblage. Other than pottery, the lifeways represented during this period are very similar to those of the preceding A rchaic period. A sedentary to semi-sedentary settlement pattern is indicated with a broadspedrum subsistence strategy concentrated on hunting, gathering, and at least some agriculture. A population increase is suggested based on an increase in the number of archeological sites. Also indicated is an increase in the size of social groups. Site distributions include the location of villages along the river or adjacent to small drainages, and specialized activity sites elsewhere such as hunting camps in the mountains and plant gathering and processing sites in the basins (Carmichael 1985).

The Dona Ana phase has been poorly defined due to a lack of excavations of sites dating to this period. Some distinguishing characteristics which differentiate this phase from the succeeding one include the introduction of painted ceramics, the building of small pueblos, and the concentration of the village sites in areas most suitable for agricultural pursuits (O'Laughlin 1980). Local painted wares include El Paso Polychrome and El Paso Red-on-Brown. Also among the 
painted ceramics are some non-local wares such as Mimbres Black-on-White, Three Rivers Redon-Terracotta, Playas Red, and Chupadero Black-on-White (Carmichael 1985). There is some trouble however, differentiating these sites from those of the preceding and succeeding phases based merely on surficial scatters or concentrations of ceramics (Whalen 1978).

El Paso phase sites have been much more extensively investigated than sites dating to any of the other periods. Communities tended to consist of a greater number of people than were included in earlier periods, although kinshipstill was apparently the leading factor of membership in social groups. A population increase is not necessarily indicated. Though there is an expansion of site locales along the river, there is an abandonment of site locales along the alluvial fans. Non-local ceramics are fairly abundant, as are shell artifacts, indicating an increase in interregional interaction. Again, habitation sites are generally located along the river or near major drainages where agriculture could be easily practiced; these habitation sites, unlike those of the Mesilla phase, appear to have been occupied on a permanent or near-permanent basis. Sometime around A.D. 1400, the area was largely abandoned, possibly for the same reasons that areas elsewhere in the southwest were also abandoned (O'Laughlin 1980).

\title{
SITES ALONG THE WESTERN FLANKS OF THE FRANKLIN MOUNTAINS
}

\author{
Site Distributions
}

The site distributions, by time period and by site type, were briefly mentioned above; however, the following discussion is intended to summarize known descriptions andidentifications of those sites along the western slopes of the Franklin M ountains andalong the river, all within the bounds of the state. of Texas. A dditional information on some of these sites is available in Gerald (n.d.) andin the various reports on the Keystone Dam project (O'Laughlin 1980; Fields andGirard 1983; Carmichael 1985). In total, one-hundred and two sites with prehistoric components have been recorded for this area. There is no site data for nine of these sites other than location. Of the remaining sites, two are located high in the mountains, seven are located on the middle slopes, and 84 are located along the lower mountain slopes and terraces of the river. All site data that follows was taken from the site record forms on file at the Texas Archeological Research Laboratory (TARL) at the University of Texas at A ustin.

The two sites high in the mountains are identified as small camps based on the presence of burned rock in addition to their lithic scatters. A mong the lithics identified were both scrapers and chopper tools, indicating perhaps functional usage as hunting camps. Some debitage was present at each, though no coresor hammerstones were recorded. N either of these sites could be identified to period of occupation due to a lack of temporally diagnostic artifacts.

The seven sites along the middle slopes are more diverse though all were identified as camps with lithic scatters. They range in size from $3750 \mathrm{~m}^{2}$ to $70,000 \mathrm{~m} 2$ and in elevation from $1300 \mathrm{~m}$ to $1500 \mathrm{~m}$ amsl. Two of the five small camps, $3000 \mathrm{~m}^{2}$ and $6125 \mathrm{~m} 2$ in size, and the large camp, 70,000 m2, consist of lithic debris indicative of a lithic procurement area. Two others 
had scrapers, bifaces, and debitage; and the remainder, including a middle-sized camp of 24,000

$\mathrm{m}^{\mathrm{Z}}$, had only scattered lithic debitage in addition to the burned rock. Based on this data, the functional purposes of these sites along the middle mountain slopes had greater variation than those higher on the slopes. Some indicate use as hunting camps, others consist of debris more indicative of lithic procurement areas. Again, due to a lack of temporally diagnostic artifacts, these sites could not be assigned to any particular period of occupation.

Eighty-four sites lay along the lower foothills of the mountains and the terraces of the river. The vast majority of these sites (71), particularly those along the foothills, are lithic scatters occasionally accompanied by fire-cracked rock hearths. These sites range in size from $1 \mathrm{~m}^{Z}$ to $60,000 \mathrm{~m}^{\mathrm{Z}}$; none had any temporally diagnostic artifacts. The next most common site type were those identified as short-term campsites; however, three of these nine sites do not appear to differ in content from the lithic procurement sites. One of these was recorded as dating to the Late Archaic and the Mesilla phase. Of the remainder, two differ by having brownware ceramics present, thus dating the sites to at least the Mesilla phase. The last four sites have fire-cracked rock hearths and some lithic debitage, though no signs of having been used specifically for lithic procurement or hunting. None of this last group of sites was associated with any diagnostic artifacts. Four of the sites along the terrace of the Rio Grande, including 41EP880, were recorded as habitation sites. These range in size from $4500 \mathrm{~m}^{\mathrm{Z}}$ to $40,000 \mathrm{~m}^{\mathrm{Z}}$. On three of these sites, brownware ceramics were reported, thus dating them to at least the Mesilla phase; only 41EP880 was tested, therefore at none of these sites is there definite evidence of a pithouse occupation. The fourth site had both El Paso Polychrome and Chupadero Black on White ceramics as well as apparent house foundations. This site, then, dates to the El Paso phase.

\section{Lithic Raw Materials}

Lithic raw material types were reported for all but ten of the above-mentioned lower sites. Of the lithic procurement sites for which this data was recorded, rhyolite material was reported as the dominant type exploited at 56 sites; and rhyolite being the only material present at 39 of these sites. The rhyolite includes the Thunderbird, flow-banded, and at least two types of unidentified or poorly described rhyolites. Other materials, less frequently exploited, include various types of chert, quartzite, basalt, mudstone, and, in far lesser quantities, obsidian. At the campsites, chert, quartzite, and sandstone are the only raw material types mentioned; there is no data for three of these sites. Habitation sites contained Thunderbird and flow-banded rhyolite, chert, quartzite, andesite, limestone, and obsidian, no lithics were reported from the El Paso phase site. By far, the raw material most frequently in evidence at the sites along the western flanks of the mountains was rhyolite of two primary types. Rhyolites are still abundant along the slopes today. 


\section{FIELD METHODS}

Initially five test units, $1 \times 1 \mathrm{~m}$ in size, were set up for excavation. These were scattered along the length of the right-of-way, paralleling the road from a point $32 \mathrm{~m}$ northeast of the nearest cross-street, Santiago Road, toa point 14 m southwest of theSahara Sportswear fence line. They were numbered sequentially from 1-5 in this same direction (Figure 5).

Prior to starting the excavation of Test U nits 3-5, a possible scattered rock feature was exposed in Test U nit (TU) 1. Test U nits 6 and 7 were then opened adjacent to TU1 to the east and south, respectively. Test $U$ nit 8 was set up just northeast of Backhoe Trench 2 and north of Backhoe Trench (BHT) 4 to expose what was thought to be a possible surface identified in those trenches. Test Unit 10 was located far downslope, to the southwest of other units, just $11 \mathrm{~m}$ from Santiago Road. This location was selected to further refine the limits of the subsurface deposits at the site. These all were $1 \times 1 \mathrm{~m}$ in size and oriented toward magnetic north.

Test Unit 9 was of an irregular size, $1.5 \mathrm{mx1.2} \mathrm{m}$, and was not set up in the same northsouth direction as the other units but, rather, was set up parallel to the roadway. Its location, on thesouth side of the road, was selected to test a rock alignment that was visible within the existing right-of-way. The size and orientation of the unit, then, were determined by the size of the rock concentration. Theinitial plan for excavation of the unit called for cross-sectioning the "feature" in two directions;thus only a quarter of the unit was excavated. The unit likely would have been expanded if there had been a subsurface element to the feature. Since this feature did not extend tothe subsurface and, in fact, was determined to be unassociated with the prehistoric habitation of the site, the unit was only partially excavated.

All but two units were excavated in $10 \mathrm{~cm}$ arbitrary levels. The depths were measured, in all cases, from the surface corner stakes for each unit with the highest beginning elevations, as determined by transit readings from Datum $B$ just north of the right-of-way. The two test units that were exceptions to this rule were Test U nits 6 and 7, adjacent to TU 1 . Test U nit 6, Level 1 was $16 \mathrm{~cm}$ deep due tothe northwesterly downward slope of the unit. The southeastern corner was higher than the others because it cut into the side of a dune. The decision to include $16 \mathrm{~cm}$ in the top level was made to even the ending elevations of all other levels with those in TU1, thereby allowing for cornson of the depths of artifacts. Test Unit 7, L evel 1 was $19 \mathrm{~cm}$ thick for thesame reasons as used in excavating TU 6 . The surface of the southeast comer of this unit was much higher than the other portions of the unit because it cut into the side of the same dune. The bottom of Level 1, in this case, was even with the bottoms of Level 2 in both adjacent units.

Six of the ten test units were excavated to $20 \mathrm{~cm}$ below the last level in which cultural debris was recovered; in effect, they were excavated through the cultural levels and to sterile soil. One of the other units, TU 4, still had cultural material as of Level 11. However, the lens of large gravels which underlay the cultural deposits in most portions of the site prevented further excavation. None of the three contiguous Test Units, 1, 6, and 7, was dug completely to sterile soil. Test Unit 1 was excavated the deepest, through Level $6(60 \mathrm{~cm}$ below the surface). 


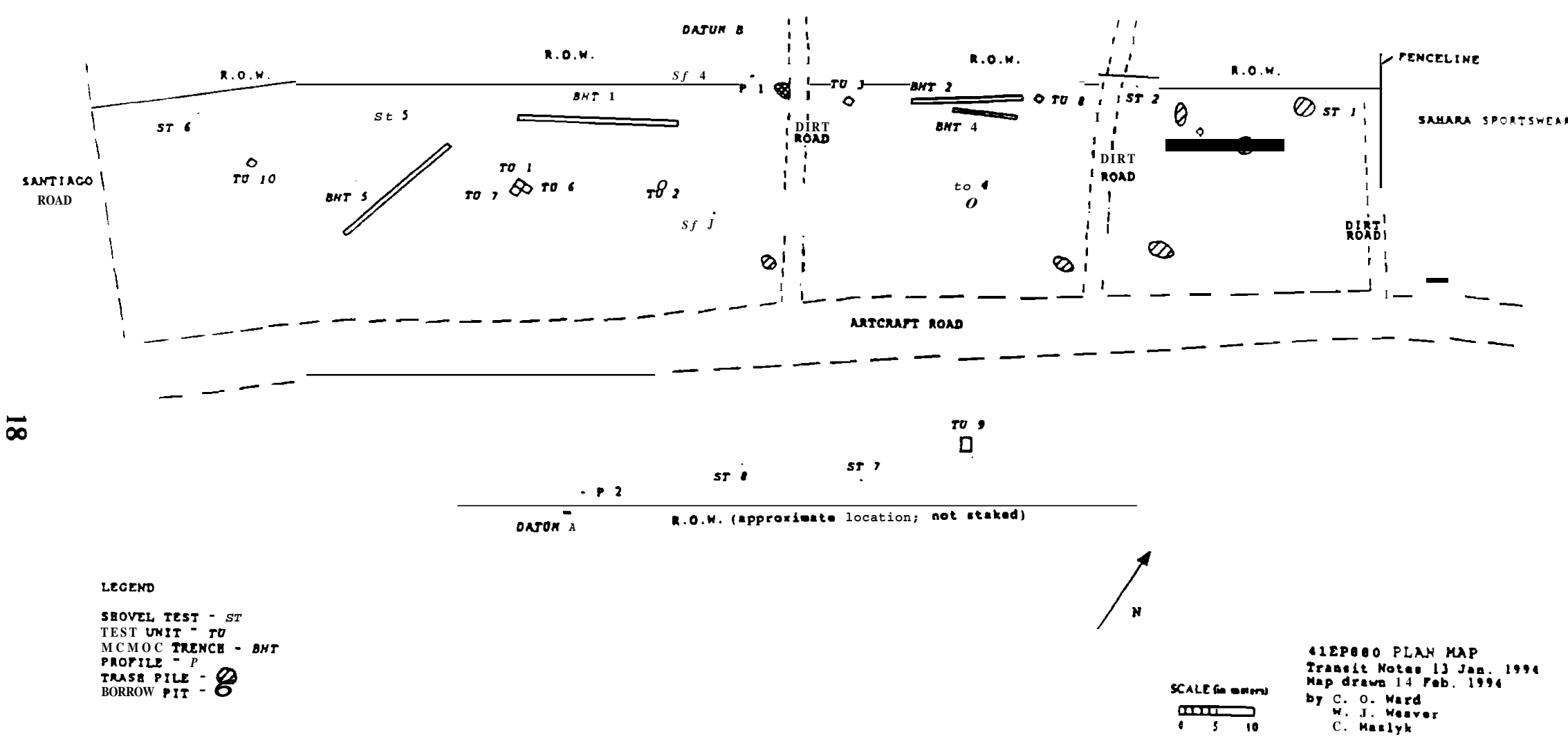

Figure 5. Site map of 41EP880 showing test unit, backhoe trench, and shovel test locations and selected surface relative elevations. 
Due to a paucity of recovered material and the likelihood that the material had eroded from upslope, the unit was abandoned at this level. Because TU 1 was dug to a deeper elevation, TU 6 and TU7 were not. Excavation was halted in both units at the bottom of Level 6 and Level 3, respectively.

Placements of the shovel tests were chosen to fill in areas where neither test units nor backhoe trenches were dug. They were not dug by levels, but each two shovelsful of dirt, representing usually $<10 \mathrm{~cm}$, was screened separately. Thus, it was known at all times where anything was found within the shovel test.

A profile was drawn of a unit wall only in the case of the northern wall of TU 4, where a vague difference was noted in the soil colors. No textural or content differencesaccompanied this change. No other stratigraphic changes were noted in any of the test units above the gravel lens underlying the site. Though this situation may seem unusual, the severe disturbances noted on site and the general homogeneity of the soils may somewhat explain the problem of stratigraphic differences within the test units.

Two vertical profiles were cut, one on the north side of the road near the right-of-way and one on the south side of the road. N either of these was cut for the purpose of careful archeological excavation, and none of the soil removed during the cutting was screened. The purpose in each case was to look for disturbances, lenses, and other phenomena visible in the vertical walls which might explain some of the stratigraphic problems. In each of these cases, a profile drawing was made of the exposed wall; differences were noted, soil colors named by M unsell number, and all associated cultural material was noted.

All soil removed from any of the test units and shovel tests was screened for cultural material through $1 / 4$ in. hardware cloth. If any artifact was found on the screen, it was bagged by level or shovel test and kept separate from other recovered artifacts. These bags were labeled by unit, level, excavators, date of excavation, and site number.

Backhoetrenches (BHT) were dug to expose much larger and deeper areas within the site than would otherwise have been feasible. Their locations were again chosen to sample a large area within the right-of-way that was not exposed in TU 1 to TU 7. Of the five trenches, only two revealed any cultural debris; the only surfaces identified were relatively recent historic surfaces. A profilewas drawn only of the eastern end of Trench 2, in which these surfaces were identifiable in the profile. Trench 2 is also the location where most of the cultural debris was recovered from the trenches. No surfaces, soil variations, or cultural debris were visible in any of the other walls of the trenches.

Surface artifacts, which were collected at one time during a thorough examination of the entire site area within the right-of-way, were separated only by portion of the site from which they were collected. For this purpose, the site was split into thirds; the south side of the road, the west half of the site north of the road, and the east side of the site north of the road. Only tools such as dart or arrow points, bifaces, modified debitage, and ceramics were collected from the surface of the site. 


\section{RESULTS OF FIFID INVESTIGATIONS}

\section{BACKHOE TRENCHES}

Five backhoe trenches were dug on site. Placement was dictated by the need to observe the vertical andhorizontal extent of the subsurfacesite deposits within the right-of-way. Only in two of the trenches were any cultural deposits observed.

Trench 1 was dug midway down the slope from the southwestemmost dirt road to determine if the deposits downslope in TU 1,6, and 7 were part of an in situ cultural occupation level. No cultural material was observed in the trench and no stratigraphic levels were identified. The trench was $0.9 \mathrm{~m}$ wide, $13 \mathrm{~m}$ long, and reached a maximum depth of $1.8 \mathrm{~m}$, the deepest of any of the trenches. At approximately $1.7 \mathrm{~m}$, a layer of large ( $>15 \mathrm{~cm}$ in size) gravels was noted.

Trench 2 was located midway between the two dirt roads and was dug within $2 \mathrm{~m}$ of the right-of-way line. It was $0.9 \mathrm{~m}$ wide, $1.4 \mathrm{~m}$ deep, and $9 \mathrm{~m}$ long. Toward the northeastern end of the trench, a large ground and pecked stone was retrieved from the southern wall at $0.34 \mathrm{~m}$ in depth. This artifact was found at the bottom of deposits identified as drift sand. A distinct line was visible delineating the sand above this point from the next level below it. On the surface the sand manifested itself as a pile forming from the southwest. The difference between this top layer and the one bel ow it was further defined by a layer of styrofoam approximately $20 \mathrm{~cm}$ long. The second strata of sand was $30 \mathrm{~cm}$ thick at the northeastern end of the trench and extended for a distance of $2.8 \mathrm{~m}$ along the length of the trench before disappearing. Within this strata, a $12 \mathrm{~cm}$ long core of ignimbrite was recovered, again near the bottom of the layer. The differences between these layers were subtle, being determined only by slight color changes, accompanied by no changes in texture or content of the deposits. Two more distinct color changes were noted among the lower deposits in this trench (Figure 6). In neither of these color changes was any cultural debris noted, either historic or prehistoric in age. At the bottom of this trench was a lens of large gravels at a slightly higher depth than noted in the previous trench.

Trench 3, located between the northeasternmostdirt road and the Sahara Sportswear fence line, revealed no subsurface cultural deposits and no discernible changes in strata. The deposits all appeared to be homogenous light brown sands with no substantial natural or cultural inclusions. The trench was $0.9 \mathrm{~m}$ wide, $1.4 \mathrm{~m}$ deep, and $11 \mathrm{~m}$ long.

Trench 4 was dug at a slight angle from Trench 2 to further expose what was thought to be the only area on site which might be undisturbed. Potentially, in situ subsurfacedeposits existed in the trench. A single flake was noted in the upslope end of the trench at roughly the same elevation anddepth as the ground and pecked stone in Trench 2. No distinct color or texture changes were noted in the deposits as were noted in Trench 2 . The reasons for this are unclear, since this upslope end of trench 4 is just 1.5 m east of the upslope end of Trench 2. 


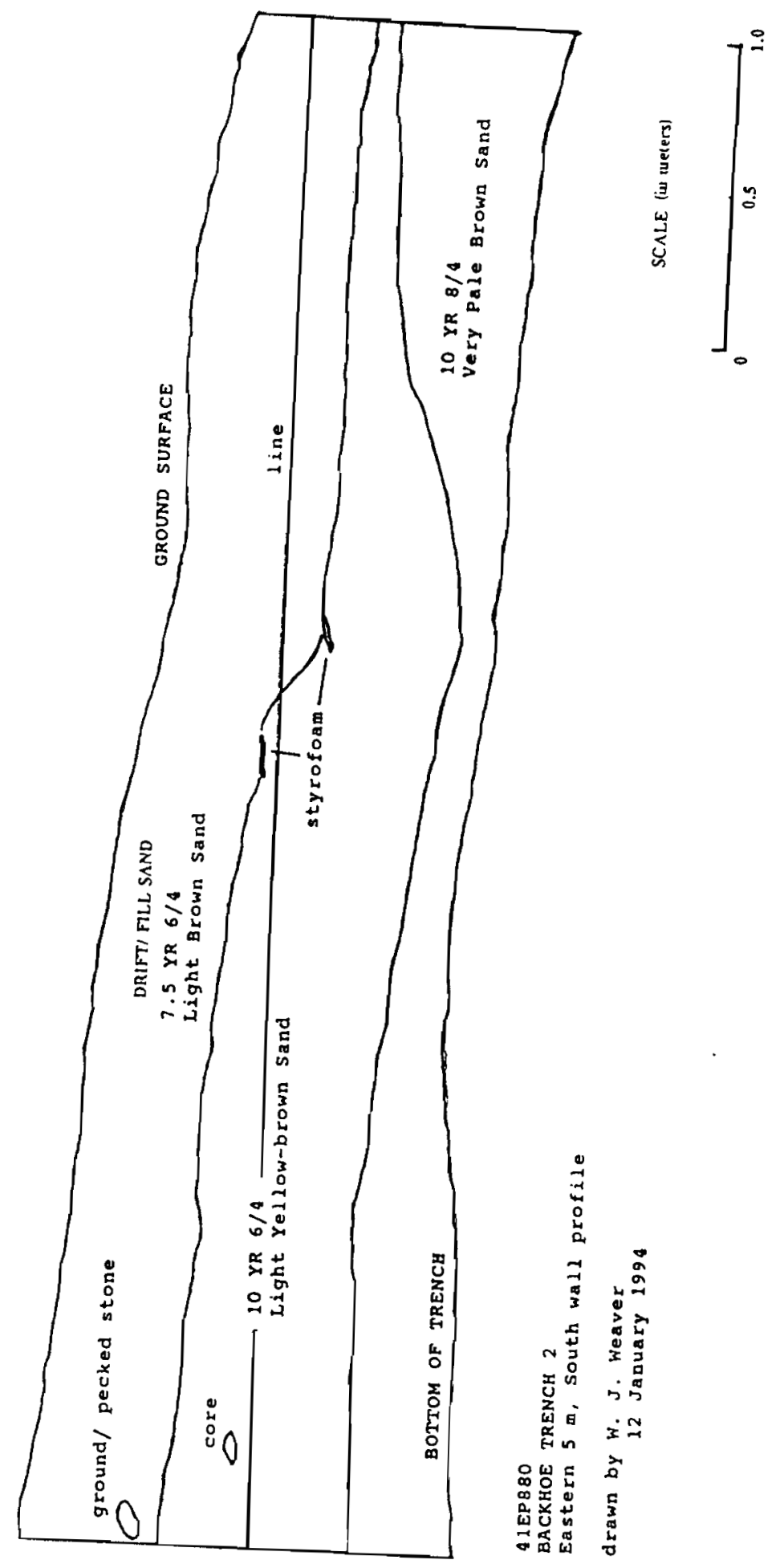

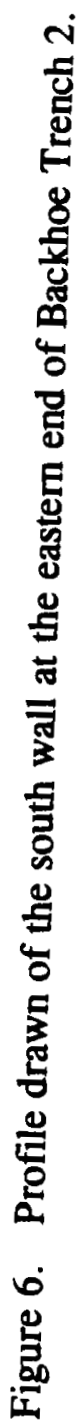


Trench 4 was $1.4 \mathrm{~m}$ deep, $0.9 \mathrm{~m}$ wide, and was $5.5 \mathrm{~m}$ in total length. The one flake recovered from the trench was determined to be from the same deposits as the ground and pecked stone, based on elevation. Therefore the opening of TU 8 served to define the context of the flake as well as that of the ground/pecked stone and the ignimbrite core in Trench 2.

Trench 5 was dug far downslope of all others to further confirm that the downslope surface cultural debris had indeed eroded from deposits further upslope. No cultural debris was noted in the trench, and natural strata were not identified. The gravel lens noted in all the previous trenches was not identified within the $1.4 \mathrm{~m}$ depth of this trench. It was $11 \mathrm{~m}$ long, running nearly north-south, and $0.9 \mathrm{~m}$ wide.

\section{SHOVEL TESTS}

A total of eight shovel tests was dug on site; the shovel test locations primarily followed the edge of the right-of-way. This method was followed due to the presence of some obvious and some less visible disturbances located primarily within $5 \mathrm{~m}$ of the existing roadway. The most likely location for undisturbed deposits on site for this reason lay closest to the edge of the new right-of-way. Running from northeast to southwest along this line were Shovel Tests 1, 2, 4, 5 , and 6. All shovel tests were $0.4 \mathrm{~m} \mathrm{x} 0.4 \mathrm{~m}$ in diameter. All deposits were screened through $1 / 4$ in. hardware cloth; no artifacts were recovered from any of the tests.

Shovel Test (ST) 1, located just $4.5 \mathrm{~m}$ from the Sahara Sportswear fence line and $1.4 \mathrm{~m}$ from the right-of-way, was dug to a depth of $60 \mathrm{~cm}$, at which point the gravelly lens underlying most deposits on site was reached. Three pieces of glass, several small pieces of plastic, and two small chert flakes were noted in the top $40 \mathrm{~cm}$. Nothing was noted between 40 and $60 \mathrm{~cm}$ depth. The deposition through about $55 \mathrm{~cm}$ was a homogenous, loose sand with few natural inclusions and no cultural material.

Shovel Test 2, located $15 \mathrm{~m}$ downslope and within the same distance of the right-of-way, was near the northeasternmost of the two dirt roads cutting through the site. Probably due to the road, the top $20 \mathrm{~cm}$ of deposits were an extremely loose sand with virtually no gravels. Several pieces of styrofoam were noted in this top layer. At $30 \mathrm{~cm}$, the deposits became more firmly packed, though the content did not change. Between 40 and $60 \mathrm{~cm}$ depth, the sand remained largely the same except for a slight increase in the amount of gravels. Four small flakes were found in this $20 \mathrm{~cm}$ interval. From $60 \mathrm{~m}$ to $75 \mathrm{~cm}$, a flake, some roots, and two pieces of styrofoam were noted among the deposits. At $75 \mathrm{~cm}$, the walls of the test began collapsing, and the test was halted.

Shovel Test 4 was located $35 \mathrm{~m}$ downslope from TU 2. It was $6.5 \mathrm{~m}$ southwest of the second dirt road cutting through the site perpendicular to Artcraft Road. The top $40 \mathrm{~cm}$ of loose sand produced just two flakes and a quantity of pea gravels. The bottom $35 \mathrm{~cm}$ revealed no additional cultural debris and a gradual increase in gravels. From $65-75 \mathrm{~cm}$, the sand became slightly more compact and extremely gravelly such that deeper excavation would have been very difficult. 
Twenty-eight meters downslope, southwest of the last test, shovel test 5 was placed within $2 \mathrm{~m}$ of the right-of-way. The test was dug to $75 \mathrm{~cm}$ and revealed no cultural debris. A gain, the top $15-20 \mathrm{~cm}$ was extremely loose with only a few gravels as inclusions. B elow this depth, the gravels became more plentiful and the soil more compact though no color or texture changes were noted.

The last shovel test al ong the right-of-way, ST 6, was located another $17 \mathrm{~m}$ southwest of the previous location. It reveal ed a single small chert flakein the entire $75 \mathrm{~cm}$ depth. The typical increase in gravels was noted beneath $40 \mathrm{~cm}$. The flake was located in the top $40 \mathrm{~cm}$.

Shovel Test 3 was dug $4.2 \mathrm{~m}$ east of TU 2 just $8 \mathrm{~m}$ northwest of the existing pavement edge on A rtcraft Road. There were two piles of modem trash located nearby, and disturbance along the roadway was evident within the vicinity. This location was chosen to check the surface disturbance in the area for its subsurface extent. A large piece of styrofoam ( $>5 \mathrm{~cm}$ in length) was found in the top $20 \mathrm{~cm}$, where the fill was primarily loose blow sand. Nothing except for pea gravel was noted between 20 and $40 \mathrm{~cm}$; below $40 \mathrm{~cm}$, a single small ignirnbrite flake was noted. As in most units, the size and frequency of gravels increased greatly between $40 \mathrm{~cm}$ and the bottom of the test at $75 \mathrm{~cm}$.

Shovel Tests 7 and 8 were located along the existing right-of-way on the southeast side of A rtcraft Road. B oth were located about midway up a slope leading from the road to the original ground surface. The top of this slope is thought to be located at the edge of the right-of-way. Shovel Test 7 was located $10 \mathrm{~m}$ from the edge of the pavement and $25 \mathrm{~m}$ northeast of the right-ofway stake that also acted as primary horizontal and vertical datum on site. In the top $35 \mathrm{~cm}$, eight flakes of chert and ignirnbrite materials were noted; between 35 and $75 \mathrm{~cm}$, no cultural debris was noted. The deposits consisted of a moist sand from $0 \mathrm{~cm}$ to $65 \mathrm{~cm}$ and a silty dry sand from 60 $\mathrm{cm}$ to $75 \mathrm{~cm}$; the gravel lens was reached at $75 \mathrm{~cm}$ and the test was abandoned.

The last test, located midway between Shovel Test 7 and the primary datum, was dug to $75 \mathrm{~cm}$ through culturally sterile sand. The gravel lens was located at the bottom of the test, 75 $\mathrm{cm}$ below the surface.

\section{PROFILES}

On the north side of the road, toward the right-of-way edge, there is a rise which at first glance appeared to have been natural and which had been cut into for the purpose of borrowing dirt (see Figure 5). It was along the southern edge of this rise that a single reworked obsidian dart point was found eroding about $70 \mathrm{~cm}$ from the surface. After the dart point was recovered, we decided to cut a clean profile into the side of this rise for the purpose of looking for intact subsurface deposits. The resulting profile (Figure 7) indicated that this rise was at least partially 


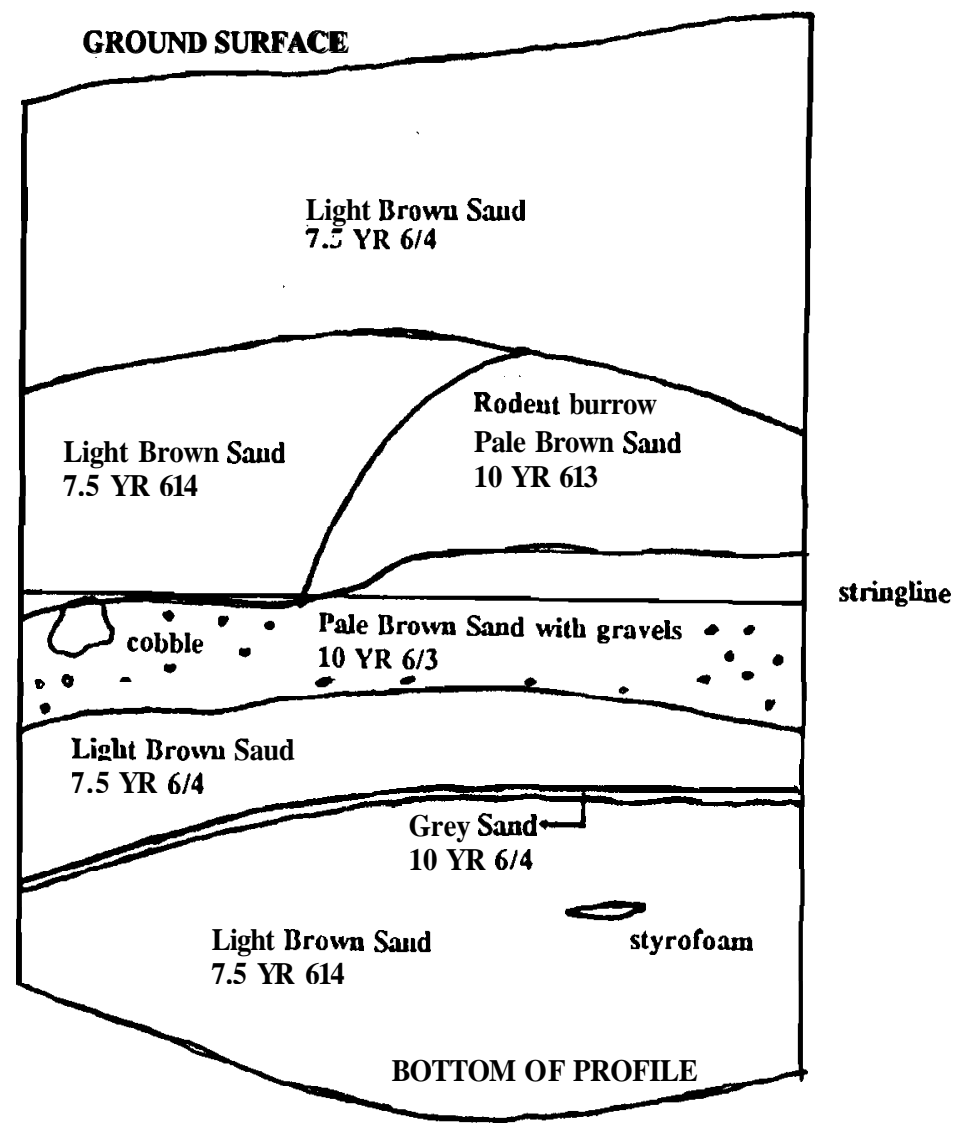

PROFILE \# 1

Northern Right-of-way Edge

drawn by $w$. J. Weaver

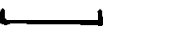

12 January 1994

Figure 7. Profile 1, at north edge of right-of-way. 
disturbed as well. Styrofoam pieces were discovered at the base of this rise in from the edge some $50 \mathrm{~cm}$. In other words, the disturbed deposits were not merely slump material from the erosion of the rise; instead, at least the southern edge of the rise had been severely disturbed, probably by machinery.

The second profile was cut into the side of the hill rising from the right-of-way on the south side of the road. No cultural material was exposed in this profile (Figure 8). This location was selected to confirm that buried deposits were not intact within the right-of-way on the south side of the road.

\section{TEST UNITS}

Ten test units were excavated. They were, for the most part, spread out singly along the length of the new right-of-way except for three units (TU 1,6, and 7) which were adjacent to one another to expose a possible feature. Six of the ten test units were dug $20 \mathrm{~cm}$ into sterile soil. Another unit was dug into the gravel lens which underlies the site; the last level in this unit contained a single flake of lithic debitage. The remaining units were the contiguously excavated units (TU 1,6, and 7) in which the quantity of cultural debris was never great and which only became sparser with depth.

Test Unit 1 was a $1 \times 1 \mathrm{~m}$ square set up toward the west end of the site. It was intended for the testing of a small scatter of more or less 20 flakes and various pieces of debitage and several broken rocks visible on the surface. The surface elevation of the unit, relative to a TxDOT stake on the south side of the road, varied from $97.73 \mathrm{~m}$ to $97.54 \mathrm{~m}$. It was dug in $10 \mathrm{~cm}$ levels from the southeast corner, $97.73 \mathrm{~m}$, through Level 6. Artifact recovery in this unit was never high but was concentrated in Level 2. In Level 3, six rocks - broken though seemingly not burned - were noted in the eastern half of the unit. At this point, excavation in the test unit was temporarily stopped and a unit (TU 6) was opened to the east to further expose this possible occupational surface. A few additional rocks were exposed in TU 6 and TU 7 (adjacent to the south of TU 1). Viewing all the scattered rock at once, it became obvious that this was not an intact feature (Figure 9); thus, excavation was continued in TU 1. A rtifact recovery in Levels 4-6 combined was less than that from Level 2 alone. A modified flake was recovered in Level 1, and a small fragment of a biface was recovered in Level 2; no ceramics or charcoal were observed anywhere in the unit. Historic debris was recovered from the top two levels. In Level 6, the only collected item was a very small, slightly battered pebble. No lithics were identified from this level. Excavation was halted at the bottom of this level due to an extreme paucity of cultural material and the probability that the cultural debris in this unit had either washed downhill from the more intensely occupied portion of the site to the east, or was predominantly washed away from this location, leaving just a trace of occupational debris.

Test Unit 2 was a $1 \times 1 \mathrm{~m}$ square set uphill to the east of TU 1. It was also located closer to the existing roadway than was the first unit. Its location was based on the presence of two small $( \pm 20$ ) lithic scatters visible on the surface nearby. The surface of this unit's southwest 


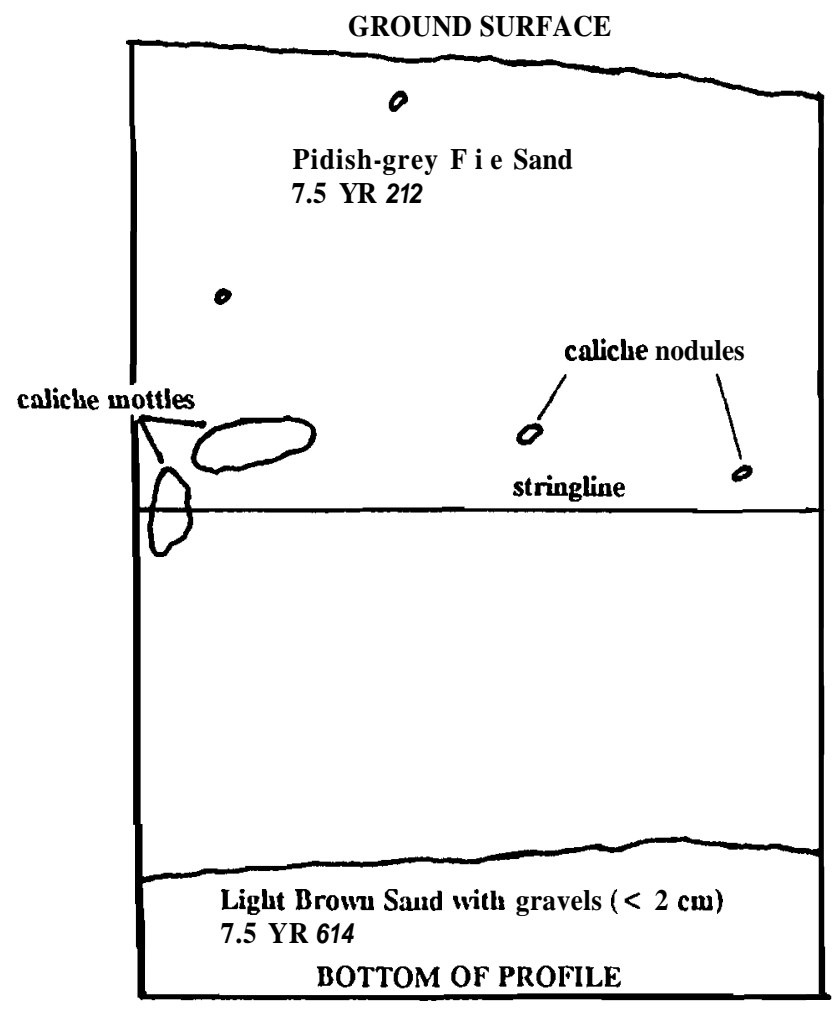

PROFILE \# 2

South Wall, South side of road

drawn by $W$. J. Weaver

12 January 1994

SCALE (in ceutiueters)

Figure 8. Profile 2, along south side of road. 

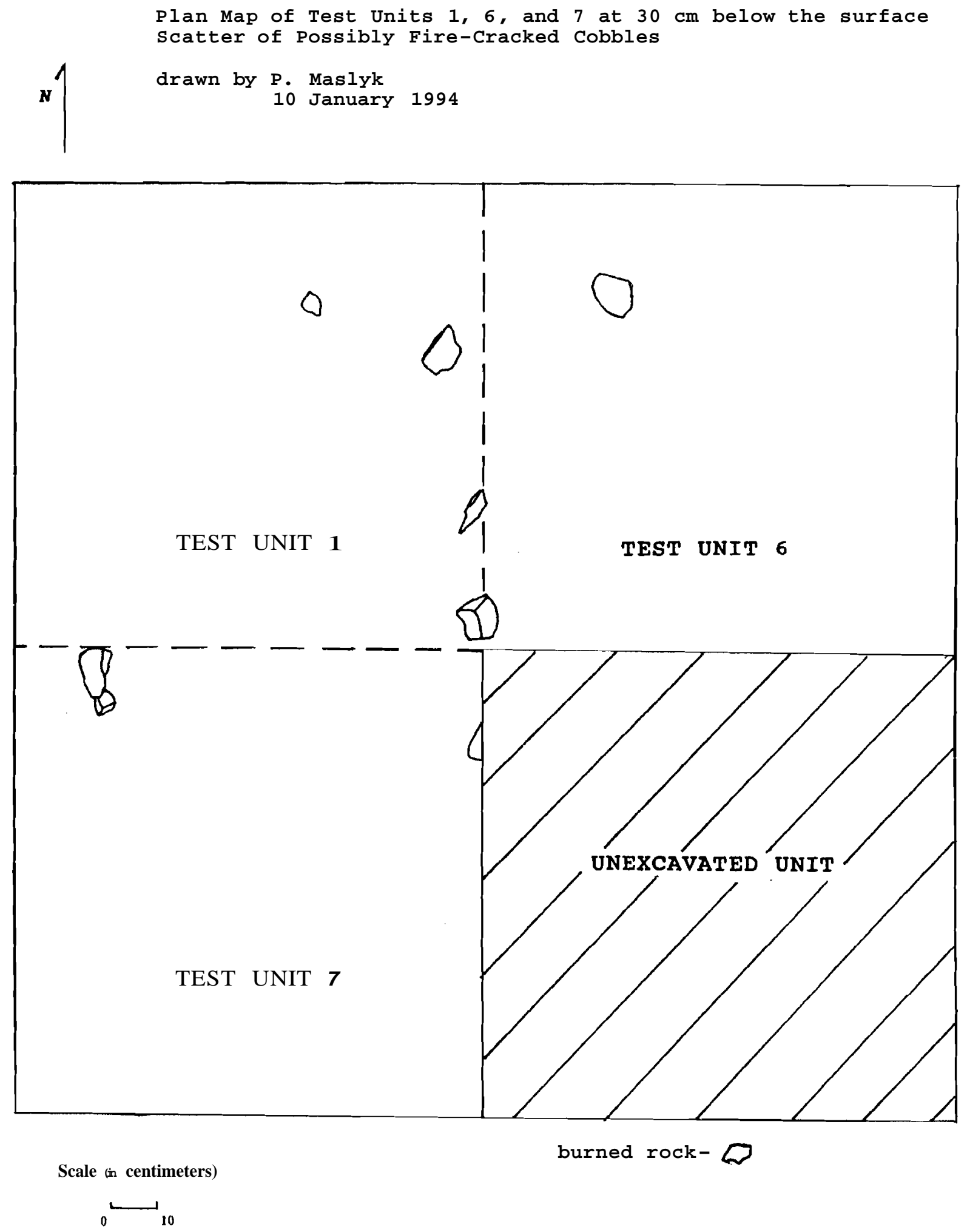

Figure 9. Plan map of rock exposed in Level 3, Test Units 1, 6, and 7. 
corner, from which elevations were measured, was $99.045 \mathrm{~m}$. Eleven $10 \mathrm{~cm}$ levels were dug; the bottom two levels were entirely sterile of cultural debris. Historic debris was again recovered within the top two levels. A single lithic tool, a core fragment, was recovered in the top level; other lithics recovered include secondary and tertiary flakes, corticate and decorticate chips, shatter and chunks (total $=39$ ). The bottom of the unit was marked by a layer of unknown thicknessof fist-sized gravels. This is the first unit in which this pattern was observed.

Test U nit 3, another $1 \times 1 \mathrm{~m}$ square, was set up alongsidethe western dirt road cutting through the site. It was located near the new right-of-way line immediatelyeast of the road. Initially, when the unit was set up, we did not know wherethe right-of-way was with respectto this unit; however, when the survey crew staked the right-of-way, the unit was located within 5 m of the northernline. This was the intentin setting the unit wherewe did. This unit was dug through L evel 8; again, the last two levelswere sterile. A gain, a gravel layer was found toward the bottom of the unit; how ever, in this case it was noted by an increasein gravel sparticularly in the last two levels. Overall recovery was fairly minimal throughthe top three levels(seven pieces of debitage: four tertiary flakes, two corticated chips, one decorticated chip) and a modifiedflake. Level 4 showed a marked increase with one secondary flake, two tertiary flakes, two corticatedchips, two decorticatedchips, and an edge modifiedflake. The increasingamounts of gravelsbegan to be noted in this level. L evel 5 containeda tertiaryflake, a splitpebble, and a small mano, and L evel 6 had a decorticatedchip and a chunk of debitage.

At this point on the site, the ground surfacewas far more level than at either of the previoustest units. With regardsto the gravel lens at the bottom, this probably indicates that the gravelswill be appearingat a more even level; possibly even at this level in the remainderof the units.

Test U nit 4, also $1 \times 1 \mathrm{~m}$ square, was set slightly ( $\pm 10 \mathrm{~m}$ ) upslopeand toward the road from TU3. It was dug through Level 11, in which a singl eflake was found. This unit exhibited both the greatestamount of prehistoriccultural debris and the greatestamount of disturbance (Figure 10). Historic materials, primarily, though not exclusively,glass fragments, w ere found mixed with the prehistoricmaterial through L evel 6 . A full $69 \%$ of all lithics recoveredin this unit, excluding only two of the bifacefragmentsand a possible hammerstone, were recovered from these disturbedlevels. The only ceramics(two sherds)found in subsurfacecontextswere recovered in Levels 1 and 2 of this unit; Level 1 is the same level from which the only two pieces of obsidian were recovered. B elow these artifacts, in Levels 3-6, were noted a leather glove, nylon rope, selenite-bleached, amber, and plate-glass fragments, bottle fragments, a chrome-plated pencil ferrule with eraser, and a candy-wrapper. M ore disturbance, in the form of a large root stain, was visible toward the center on the floor of the unit in Level 9. This root stain was visible through the bottom of Level 10 and may be responsible for the nine debitage pieces and single biface fragment found in these bottom three levels.

The gravel layer noted above for TU 2 and TU 3 was found again in this unit. In Level 7, the amount of gravels began to increase dramatically with, for the first time, a corresponding change in soil texture noticed. B ecause the soils are, for the most part, homogenous throughout the site, except for differing quantities and percentages of gravels, this type of change could only be noted by the compactness of the deposits. In the case of this unit, the gravel increase was 


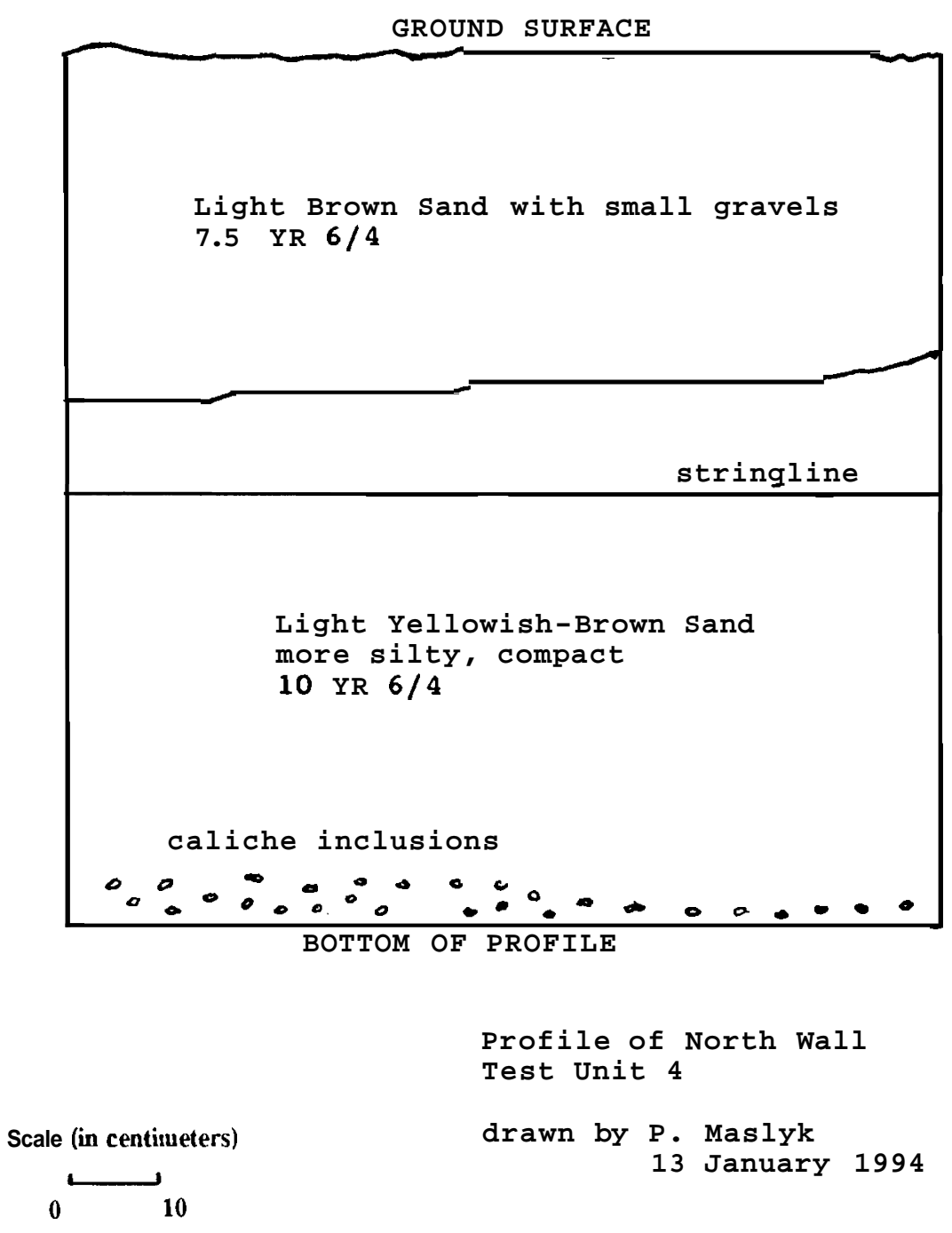

Figure 10. Profile of the north wall of Test Unit 4. 
noticed simultaneously with the increased compactness of the soils. A profile was drawn which indicates the point at which these changes were noted.

Test Unit 5 (1x1 m) was set up nearest the Sahara Sportswear fence line on the eastern end of the new right-of-way limits. The site very well might have extended onto this property at some time; however, the disturbance due to the fence line, the parking lot, and the factory itself would undoubtedly have disrupted the site. Cultural evidence in this most upslope of locations within the site area tested is much sparser than the locale downslope around TU 4. Levels 1 and 2, which consisted primarily of surface blow sand were, with the exception of a single corticated chip in Level 2, void of cultural debris.

Levels 3-5 contained the greatest amount of cultural debris: Level 3 (three secondary flakes, five tertiary flakes, nine chips, a small amount of charcoal), Level 4 (six tertiary flakes, four chips, two pieces of shatter, one mano, a small amount of charcoal), and Level 5 (one secondary flake, seven tertiary flakes, two chips, two pieces of shatter). Although these three levels account for $71 \%$ of all debitage from this unit, the only two tools found were recovered far below this $50 \mathrm{~cm}$ depth. In Level 7, seven pieces of debitage (five tertiary flakes and two decoricated chips), two edge-modified flakes, and a biface fragment were recovered. The recovery from Level 8 decreased substantially to three pieces of debitage, and the last two levels were sterile.

The charcoal which was noted in Level 3 is presumed to be contaminated, and therefore was not used for dating. A small piece of asphalt was also noted in this level, therefore revealing the possibility of contamination. The presence of gravels began in this same level. Gravels increase in number and size as the depth increases. In Level 5, the gravels begin to resemble those which were appearing in the previous units. Level 5 is also the level in which it was noted that a texture change was again occurring in the deposits.

TU 6, as mentioned above, was set up adjacent to the east side of TU 1 in order to further expose of small scattering of rocks, possibly burned, which were revealed in Level 3. This unit cut into the side of a dune with its southeastern comer, thus making this part of the unit much higher on the surface than the other comers. As a result, and due to the fact that we wanted to expose the rocks as part of the same $10 \mathrm{~cm}$ increment in excavation, Level 1 was dug to $16 \mathrm{~cm}$ below the surface of this southeastern comer. The result of this method was that the level numbers for these two units lined up together. This method did not truly skew the volumetrics for the levels between the two units, however, since only the southeastern comer was $16 \mathrm{~cm}$ higher. Most of the unit lay below the surface level of TU 1. Level 1, as a result, encompassed primarily the southeast comer, and consequently was void of artifacts. Level 2, from $16-26 \mathrm{~cm}$ depth below the southeast comer of the unit, was also sterile of cultural debris. Several small gravels were noted.

Level 3 of TU 6 had three tertiary flakes; Level 4 had two tertiary flakes and five chips and shatter. Level 5 contained a single corticated chip and one piece of shatter. Level 6 offered the most amount of cultural debris, represented by a secondary flake, two tertiary flakes, a decorticated chip, a piece of shatter, and a flaked piece of sandstone. Only a single rock was noted in Level 3 which might have been associated with those in TU 1, Level 3, but the rock was not conclusively identified as burned. Deeper testing in this unit was not done. TU 1 was selected among the three contiguous units for deep testing instead. This selection was made 
arbitrarily since no one unit showed any particular promise, and all three were thought to have associated deposits.

Test U nit 7 was opened to the south of and adjacent to TU1 in the other direction in which the scatter of rock in Level 3 was thought to have spread. L evel 1 of this unit again had the same problem as Level 1 in TU 6; the southeast comer was on the slope of the adjacent sand dune and was $19 \mathrm{~cm}$ above the surface of the northwest comer. Because of this factor and our desire to have the levels ending at the same $10 \mathrm{~cm}$ increments between the three contiguous units, the entire $19 \mathrm{~cm}$ was dug as Level 1 . However, because the remainder of TU 7 was lower than the surface of TU 1, Level 1 in TU 7 corresponded to Levels 1 and 2 in TU 1. However, the volume of Level 1 was close to that of a single $10 \mathrm{~cm}$ level. A large amount of debitage was recovered in the top two levels. Also in Level 1, two edge-modified flakes were found. In all, 18 pieces of debitage, modified flakes, and a core were recovered in Level 1; 19 lithic fragments were found in Level 2, and a single tertiary flake was recovered in Level 3. The deposits were otherwise homogenous throughout all three levels. With regard to the possible feature extending across the three units, two rocks (one $<5 \mathrm{~cm}$, one $<10 \mathrm{~cm}$ ) were found just above the floor of 2 evel 2 , equating with Level 3 in the previous two units. In all, this scatter totaled just seven or eight rocks, none of which could be determined as burned due to their igneous origins. N or was there any morphology to the distribution of the rocks which might contribute to their being labeled a feature; however, this was the most intact and obvious "feature" discovered at this site during testing. Immediately below it, as was shown in TU 7, Level 3 (below the rocks), the amount of cultural debris as represented by lithic debitage and tools dropped off tremendously. A gain, this unit was arbitrarily not selected for further investigation, and testing ended at the bottom of Level 3 (39 cm depth bel ow the surface; see TU1 notes for deeper investigation in this area of the site).

Test U nit 8, again a 1x1 m square, was excavated almost directly north of TU 4, closer to the right-of-way and at the eastern end of Backhoe Trench 2. The "east" end of BHT 4 was located just to thesouth of this unit. This location was chosen due to the discovery of a ground1 pecked stone fragment and an ignimbrite core at about $50-60 \mathrm{~cm}$ depth toward the east end of BHT 2. The depth of these finds was roughly $15-20 \mathrm{~cm}$ below what looked to be the original surface prior to the very recent and very obvious disturbances throughout the site area. The unit was dug through 11 levels ( $110 \mathrm{~cm}$ below the surface); the last two levels were found to be culturally sterile with increasing amounts of small gravels. A fairly large number of artifacts were recovered in the unit, andno obvious disturbances such as those evident in TU4 were noted. Historic debris was not present anywhere in the unit. A single ceramic sherd was recovered in Level 1, as was a biface fragment. Level 2 was represented only by a single tertiary flake. The debris picked up substantially as of Level $4(40 \mathrm{~cm}$ bs). In all, the top three levels accounted for just $13 \%$ of the total debitage from the unit. Levels $4-8$, a $50 \mathrm{~cm}$ increment, accounted for $80 \%$ of the total from the unit. The top of Level 4, $30 \mathrm{~cm}$ bs, was about equal with the point in the backhoe trench at which the previous surface level was marked with a layer of styrofoam (see trench profile, Fig. 6). The bottom of Level 6 would then equate with the point at which the ground/pecked stone was found, and Level 8 would occupy the position at which the ignimbrite core was noted. In all the units on the north side of the existing road, there is a roughly $30 \mathrm{~cm}$ level from which most of the prehistoric debris was recovered. In most areas of the site however, this level is extremely disturbed; only in this area does the apparent occupation zone seem somewhat intact. A mong the 
tools recovered in this unit were a core (Level 4), a modified flake (Level 5), and a core fragment, a ground stone fragment, and a scraper (Level 7). Level 8 contained $13 \%$ of the total debitage count for the unit.

Test Unit 9 is the only test unit opened on the south side of the road. The entire southern side of the existing road appears to be extremely disturbed and slopes drastically upward within just a few meters of the road, making the disturbances appear to be obvious. The surface along this slope, however, is littered with a large amount of lithics of all material types. Along this slope were collected several sherds of brownwares, a base fragment of a dart point, several utilized pieces of debitage, and a few cores. A single cluster of rock was noted on the surface at the bottom of the slope; again, burning could not be determined since the rocks are igneous. Though it was likely that this clustering of rock was due only to coincidence and not directly attributable to the occupation, it was selected for testing due to the possibility that this area was as disturbed as we thought. Upon clearing the surface of all vegetation, the first thing that was noted was the apparent alignment of the rocks into two parallel clusters (Figure 11). This, we thought, lent credence to the idea that these rocks were aligned only by the mechanical efforts of the road grader. In total, the scatter measured approximately $120 \mathrm{~cm}$ north-south by $150 \mathrm{~cm}$ eastwest. The two rows ran roughly east-west approximately parallel to the existing road. The northwestern comer of this feature was selected for cross-sectioning due to the fact that the north end was downhill, and the western side appeared to have more clustered rock. The unit was dug only through Level 4; the bottom two levels were sterile of cultural debris. Because of the slope on which this scatter lay, the top level would have included only a $5 \times 5 \mathrm{~cm}$ area in the northeast comer if it had been dug in standard $10 \mathrm{~cm}$ levels. Instead, the entire unit was encompassed into Level 1 which was expanded to a depth of $16 \mathrm{~cm}$. Twelve pieces of debitage were found in the top level; a burned piece of clay with a root fragment embedded in it was recovered in Level 2 . The rocks were scattered on the surface only with no subsurface feature present. The soil was a homogenous blow sand. In the end, the rock alignments were determined to not be a part of an intact hearth feature.

Test Unit 10 was the last $1 \times 1 \mathbf{m}$ unit dug at this site. It was located far downslope, just $20 \mathrm{~m}$ northeast of Santiago (Van Buren) Road. Though it seemed obvious that the site did not truly extend this far downslope, there still existed a fairly substantial amount of prehistoric cultural debris on the surface in this vicinity. Among other items, a large (but still $<2 \mathrm{~cm}$ long) piece of obsidian was collected from the surface yet further downslope from this unit. As there were no scatters of artifacts or rocks, this location was chosen very arbitrarily. The deposits consisted of a very homogenous, loose sand relatively devoid of gravels through $30 \mathrm{~cm}$ depth. In Levels 3 and 4, the amounts of gravels increased, becoming fairly abundant in Level 5 . No artifacts were recovered from the.unit in any of the levels. B ecause the deposits appeared to be at more shallow depths the further downslope the excavations occurred, it appeared that the cultural levels would have been amid the top $50 \mathrm{~cm}$ of the unit. 
Plan Map of Surface Scatter of Rock

Test Unit 9, South Side of Artcraft Road

drawn by P. Maslyk

12 January 1994
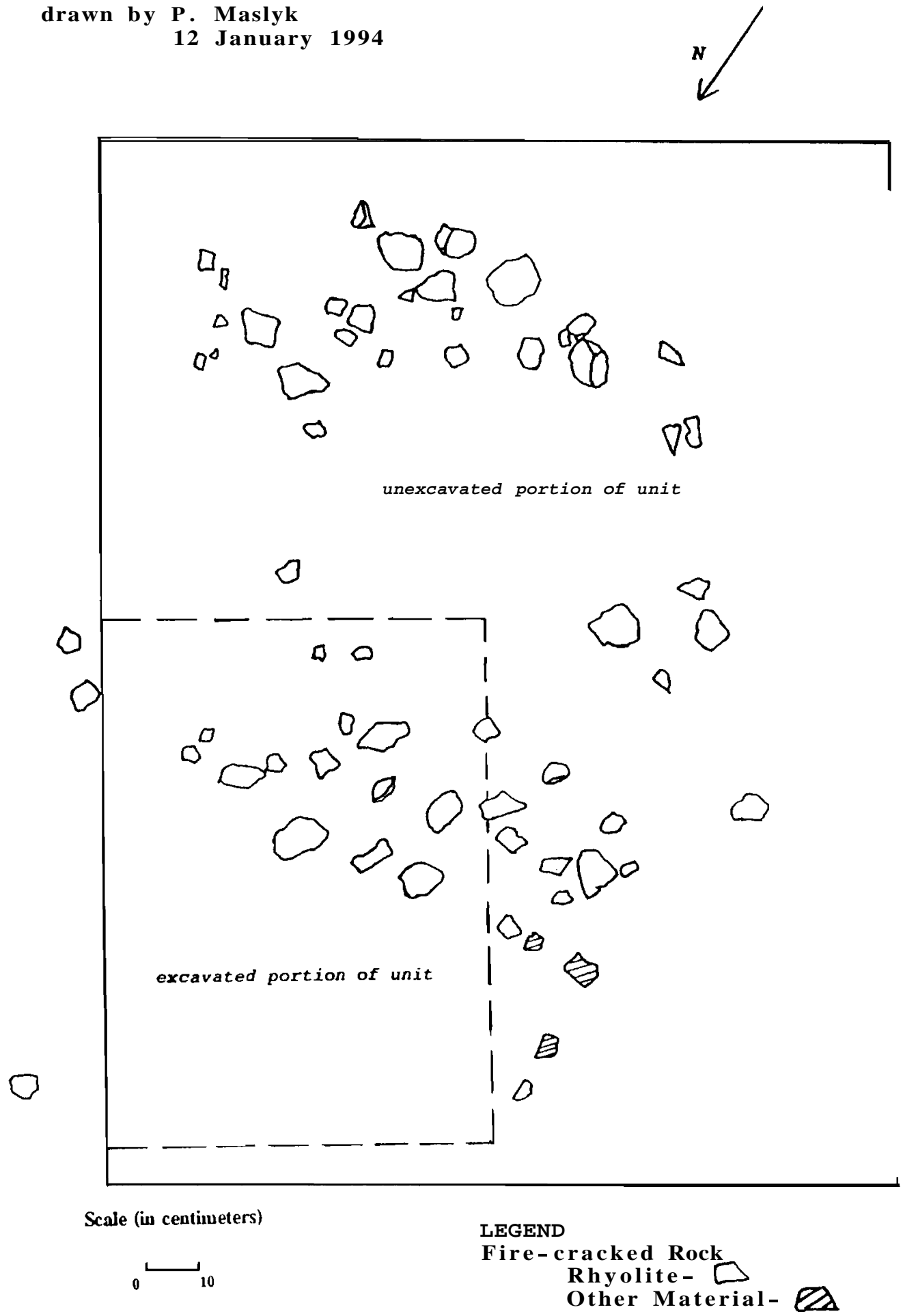

Figure 11. Plan map of exposed rock on the surface of Test Unit 9. 


\section{ARTIFACT DESCRIPTIONS AND DISTRIBUTIONS}

Three broad categories of artifacts were collected at this site: lithics, ceramics, and historic artifacts. By far, the most numerous artifacts present at the site were lithics, both in surface and subsurface contexts. Lithic artifacts include chipped, ground, and battered stone. None of the artifacts, either lithic or ceramic, were found in association with features and few are thought to have been in primary Context at the time of recovery. What follows is a brief summary of each type of artifact, the major categories of that type, particularly with regards to the lithics, and discussions of their distributions and associations when relevant. The historic artifacts collected are all very recent and therefore are not discussed below. They are, however, listed by provenience in Table 1.

\section{LITHIC ARTIFACTS}

Assorted lithic artifacts were collected during the test investigations at 41EP880, though few tools other than edge-altered debitage, ground stone, and hammerstones were identified (Table 2). The vast majority of the lithics $(90.8 \%)$ was unmodified debitage from the reduction process and the modification of existing tools. The next major category was that of edge-altered debitage (4.6\%), including both utilized and edge-modified debitage. The remaining categories, in order of decreasing percentages are cores $(1.5 \%)$, ground or pecked stones $(1.3 \%)$, projectile points $(0.5 \%)$, hammerstones $(0.5 \%)$ and a large uniface $(0.2 \%)$.

\section{Chipped Stone}

\section{Unmodified Debitage}

A total of 358 pieces of unmodified debitage were collected from the surface and subsurface deposits. Unmodified debitage, following Black and McGraw (1985:66-67), is defined as "...the pieces of lithic material removed from the parent mass (core or unfinished tool) during the manufacture of formal tools." These are further categorized as flakes, chips, and shatter. Flakes differ from chips by having a platform, or the specific "... area on the proximal end which receives the force of impact" (Jones 1985:387) during removal of the flake from the parent material and a bulb of percussion, or "...the rounded protrusion on the... inside surface of a flake just below the point of impact, caused by a ...diffusion of the force of the detaching blow" (Johnson 1991:9).

Among the flakes, there are three categories which define the point during the reduction process that the flake was removed from the parent mass. These are primary, secondary, and tertiary flakes. A primary flake has cortex covering the entire dorsal surface, thus it is part of the initial stage of the reduction sequence. A secondary flake is that which has some cortex on the dorsal surface and a tertiary flake is that which has no cortex on the dorsal surface. Both these last two categories are representative of correspondingly later stages in the reduction sequence. 
Table 1. Intrusive recent artifacts collected at 41EP880 from subsurface contexts.

\begin{tabular}{|c|c|c|}
\hline UNIT & LEVEL & DESCRIPTION \\
\hline 1 & 2 & Plassic buaon with fabric \\
\hline 2 & I & Green glass botule fragment \\
\hline 2 & 2 & Shoe string \\
\hline 4 & $\underline{\beta}$ & 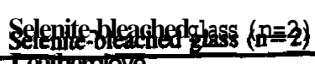 \\
\hline 4 & 4 & $\begin{array}{l}\text { Nylon rope } \\
\text { Selenite-bleached glass ( } n=2)\end{array}$ \\
\hline 4 & 5 & $\begin{array}{l}\text { Amber glass ( } n=2 \text { ) } \\
\text { Selentite-toteachedglass } \\
\text { Pencil sod eraser } \\
\text { ferrule } \\
\text { Candy wrapper }\end{array}$ \\
\hline 4 & 6 & Amber glass ( $n=4)$ \\
\hline
\end{tabular}

Chips, asmentioned above, are missing either or both the platform and bulb of percussion. Shatter is residual material from the reduction process which possesses neither a distinctive shape nor specific characteristics yet is determined to be from the reduction process due primarily to association.

Flakes make up $55.6 \%$ of the total lithic material from the site. Of this, primary flakes a re $3.7 \%$, semayflakes are $19.6 \%$, and tertiary, or interior, flakes are $76.7 \%$. The primary flake percentage is, perhaps, a less than accurate amount of the predictable percentage given that six cores were found on site, yet only eight primary flakes were recovered. The secondary flake percentage is correspondingly high, given the number of primary flakes. Tertiary flakes, however, which encompass all those flakes without cortex, is more probably an accurate sample. These include not only those flakes from the reduction sequence of the core, but also those from the reduction of tools into a finished product and flakes from the resharpening of existing tools. Given the relatively low number of cores and primary flakes recovered from the site, it is likely that little primary reduction was being done on site. Other than the alluvial cobbles which underlie the site deposits, there are few sources for lithic raw material immediately in the site area. As the earlier discussion of site distributions showed, most of the sites upslope from 41EP880 were centered around lithic procurement and the primary reduction process. The greater number of secondary and tertiary flakes recovered at 41EP880 indicate that these parts of the reduction sequence were being done on site.

Chips and shatter make up 35.3\% of the total lithics from the site. These, like the flakes, are from the reduction sequence. Chips, like the differentiation between secondary and tertiary flakes, can be separated into categories based on the presence or absence of cortex on the dorsal surface. Chips with cortex make up $17.3 \%$ of this category; chips without cortex are $51.8 \%$, 
Table 2. Provenience and identification of lithic artifacts.

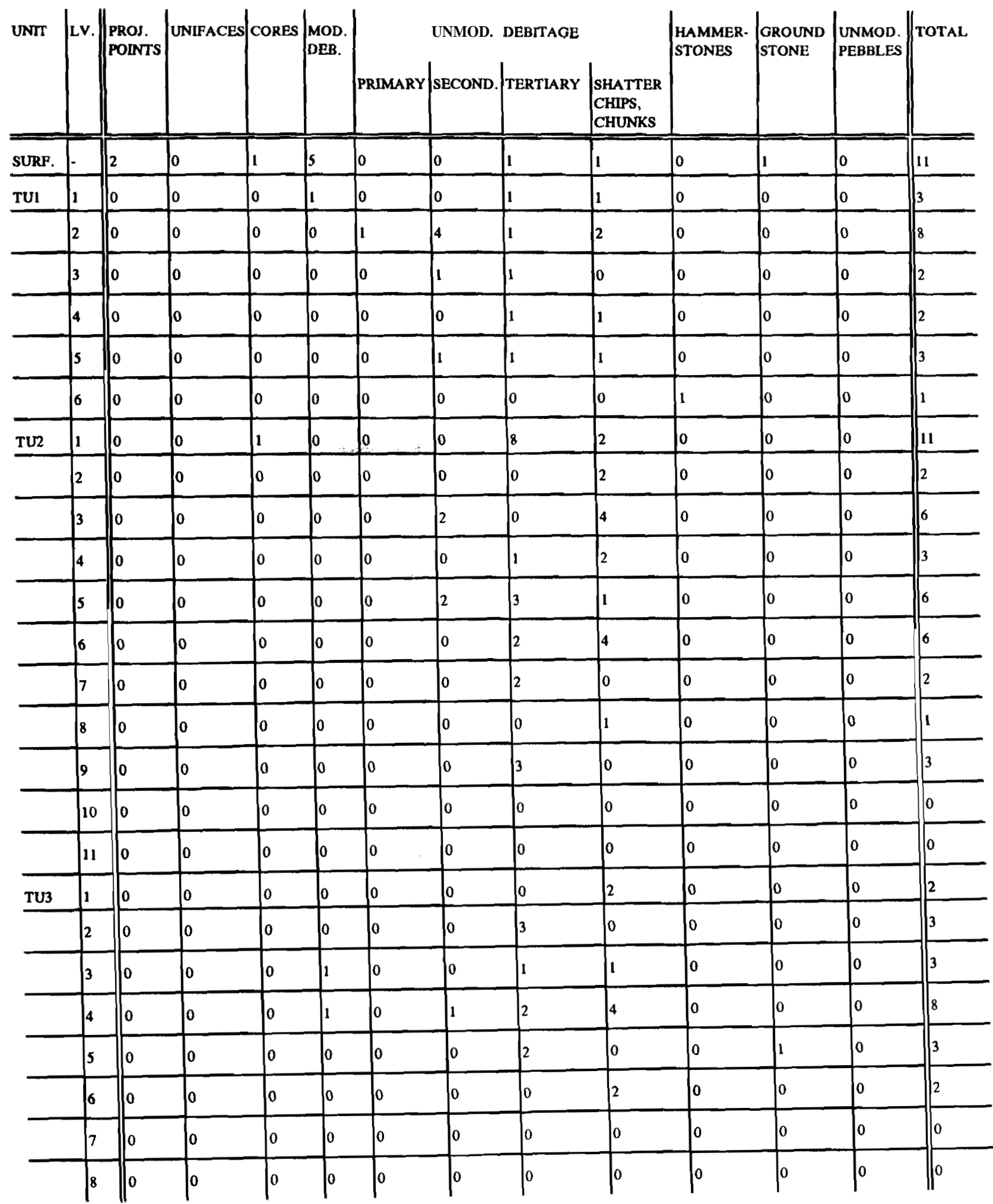




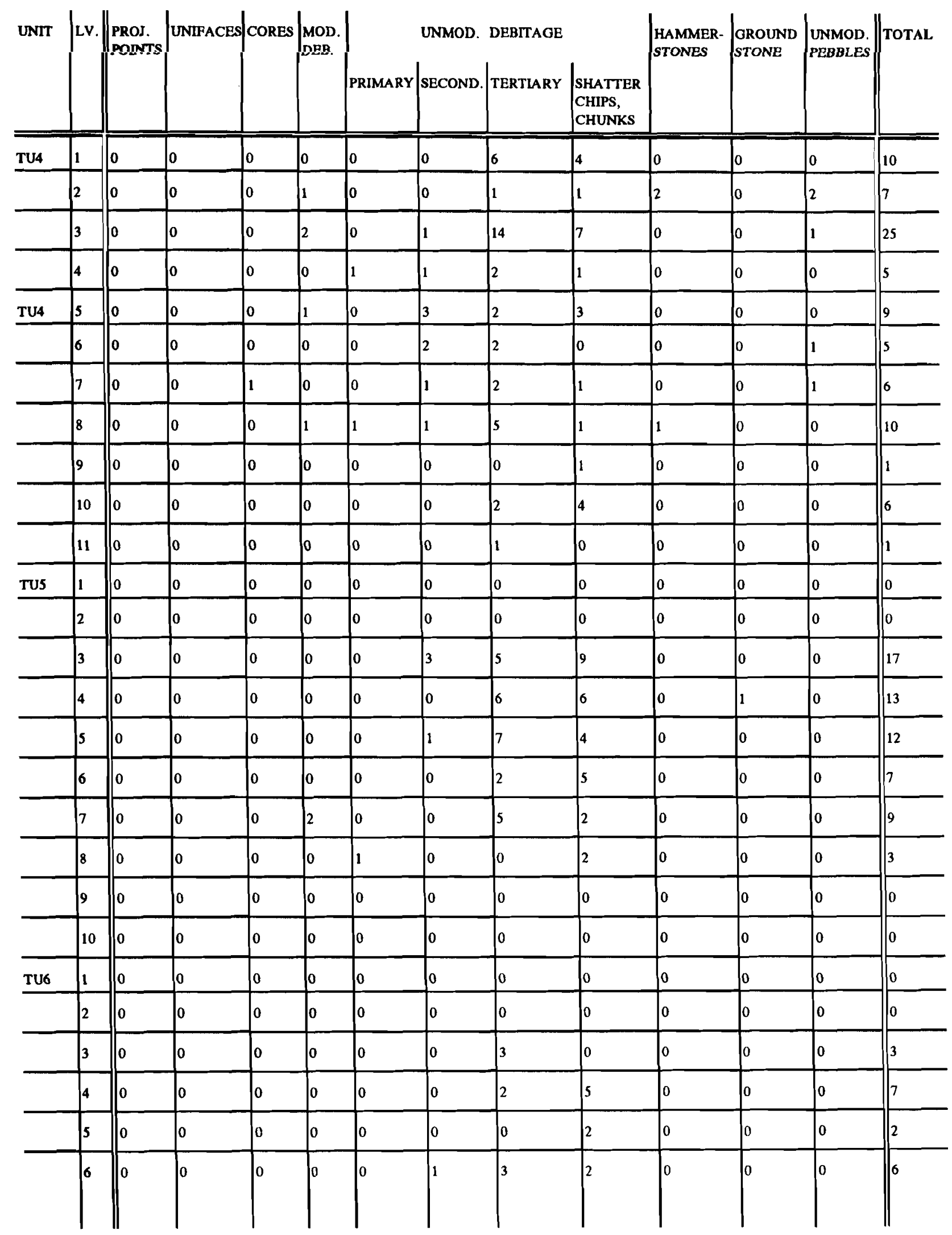




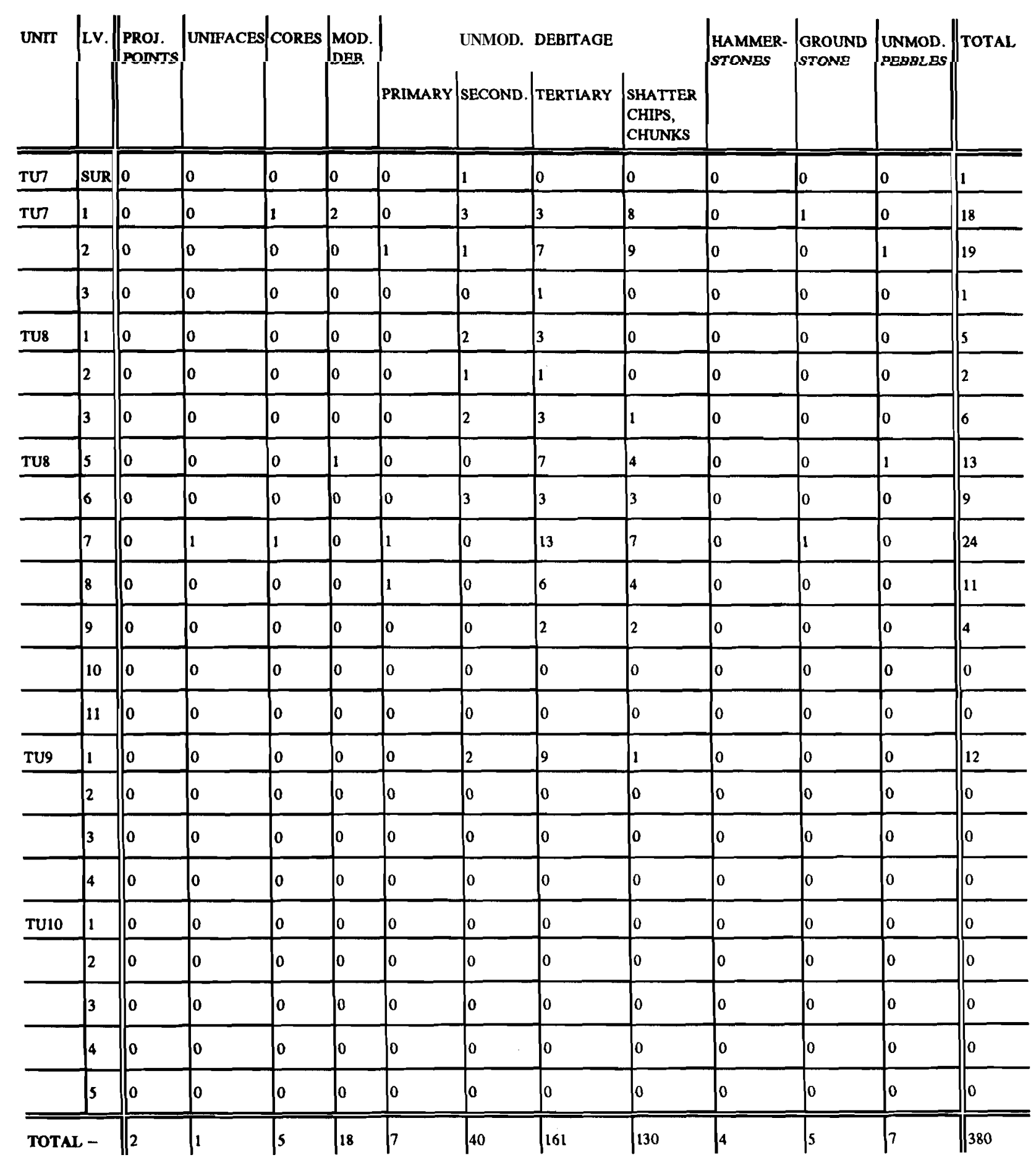


and shatter make up the remaining $30.9 \%$ of the total. Given the overall numbers of cores, and primary and secondary flakes, the corticated chips should quantify correspondingly. Given the numbers of tertiary flakes, the decorticated chips should and do, to some degree, correspond.

With regards to distribution, there is some evidence for a minor amount of association of cores with those levels which contained the greatest amounts of chips and shatter. This would be an expected pattern though in most cases the association is not obvious.

\section{Edge-altered Debitage}

Eighteen pieces of edge-altered debitage were collected from the site; five of these were collected on the surface. Of the remainder, all but one are utilized or modified secondary or tertiary flakes. The exception is a utilized decorticated chip. Five of the thirteen subsurface edgealtered pieces of debitage, including the decorticated chip, were collected from TU 4 . The rest of the subsurface specimens were scattered among Test Units 1, 3, 5, and 7.

In this report, there has been no attempt to differentiate between utilization and modification of the altered debitage. Utilized debitage are expedient tools used without prior modification such as edge straightening or sharpening. A piece of modified debitage has been prepared in some way for use as a tool. The decision to merge the two categories was made primarily due to a lack of familiarity with the raw materials of the Franklin Mountains. For some artifacts, for instance, those made from chert or obsidian, the differentiation would be obvious; however, for the coarser materials, such as the Thunderbird and Flow-banded rhyolites, the difference was considered too subtle to be certain of proper identification.

\section{Cores}

Six core fragments were recovered at the site; one was collected on the surface. None of these were complete or exhausted cores. Two were found in Test Unit 8, the remainder were scattered among TU 2,4, and 7.

The cores in TU 4 and 8 were found in close proximity to primary flakes of the same material; none of the others show such a correlation. The same cores for which there is a primary flake correlation also were found in proximity to larger than average amount of debitage in general. This case also applies to the core found in TU 8. The relationship may indicate possible lithic work stations within the site at these locations.

With regard to raw materials, four of the cores are of rhyolite from the Thunderbird formation. Two of these are of fine-grained rhyolite; the others are coarse-grained rhyolite. The other two cores are of basalt and dark gray chert. Only the chert core allows for an estimation of size: likely no more than a fist-sized cobble. No flakes could be identified specifically as coming from any of the cores.

\section{Projectile Points}

Two projectile points were collected at the site. The fragmented projectile point was collected from the surface on the south side of the road, and the complete specimen was collected from an eroding surface on the north side of the road, near Profile 1 (see map, Fig. 5). 
The fragment consists of a portion of the base of a probable dart point made from a white chert (Figure 12a). It is $1.8 \mathrm{~cm}$ long, $1.8 \mathrm{~cm}$ wide at the shoulders, $1.4 \mathrm{~cm}$ wide at the extreme base, and $0.6 \mathrm{~cm}$ thick. One of the shoulders is broken and little of the point above the stem remains. Based on the thickness and the width of the remaining portion, it is most likely a dart point fragment.

The complete specimen (Figure 12b), made from obsidian, is also of a thickness $(0.6 \mathrm{~cm})$ which suggests a probable identification as a dart point. It has, however, been extensively reworked. The reworking may have been an attempt to rework the piece into an arrow point. In other words, there is a possibility that the point, as an Archaic specimen, was collected by someone from the Late Prehistoric (Formative) period occupation of the site and modified. Its total length is $2.5 \mathrm{~cm}$, and its width is $1.6 \mathrm{~cm}$ at the shoulders. The stem is straight and the base is rounded. One face of the base is rather steeply sloped.

\section{Uniface}

This large piece (length $=9.2 \mathrm{~cm}$ ) of nearly black Thunderbird rhyolite has been modified on one face along one half of the artifact only (Fig. 13). The other end has been left intact with its original rounded, cortex-covered shape. The resulting edge is steeply angled ( $>75$ degrees). Fine pressure-flaking has been applied all along the working edge. The opposite face is flat, having been broken off from a larger cobble.

\section{Ground and Pecked Stone}

Four pieces of ground stone were found in subsurface contexts in the test units, one in Backhoe Trench 2, and one on the surface. All but two are fragmented pieces with just a small portion of the ground surface remaining.

One piece was fragmented such that very little remained of the artifact; this example was of sandstone and appears to have been fairly heavily ground. This artifact, from which little else can be determined, was recovered in Test Unit 3, Level 5. Another fragment, also of sandstone, was recovered in Test Unit 8, Level 7. It, too, is very small but is less heavily ground than the last. No pecking is evident on either of these fragments.

Two other fragments can be fairly confidently identified as mano fragments; one is of diorite, the other is of rhyolite. The diorite piece, collected from the surface on the south side of the road, has enough of the ground surface remaining to show a clear convex curvature. Again, no pecking is evident. The rhyolite fragment, collected in Level 2 of Test Unit 7, is from the edge of the artifact with both faces being ground. There is an angle between the faces however, which may indicate a wedge-shape to the completed piece. Pecking is not apparent on this artifact either.

The last two ground stone fragments are much more complete. Both seem to be made from alluvial cobbles of unidentified material, which are available in the underlying sediments of the site and probably in nearby arroyo cuts as well. Both are pecked as well as ground and both show evidence of "recent" pecking to roughen the ground surface. Figure 14 shows the complete 


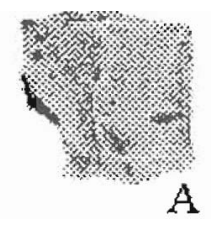

A

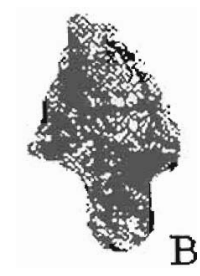

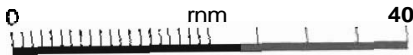

Figure 12. Projectile points: a) base of dart point recovered on surface;

b) reworked obsidian dart point eroding from edge of rise. 


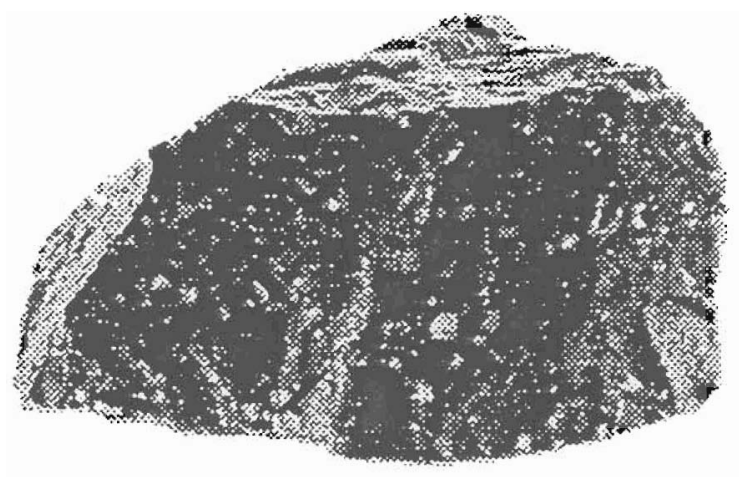

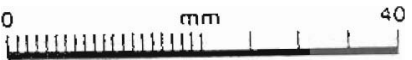

Figure 13. Large uniface recovered in TU 8, Lv 7.

Worked, steep end of uniface to the right. 


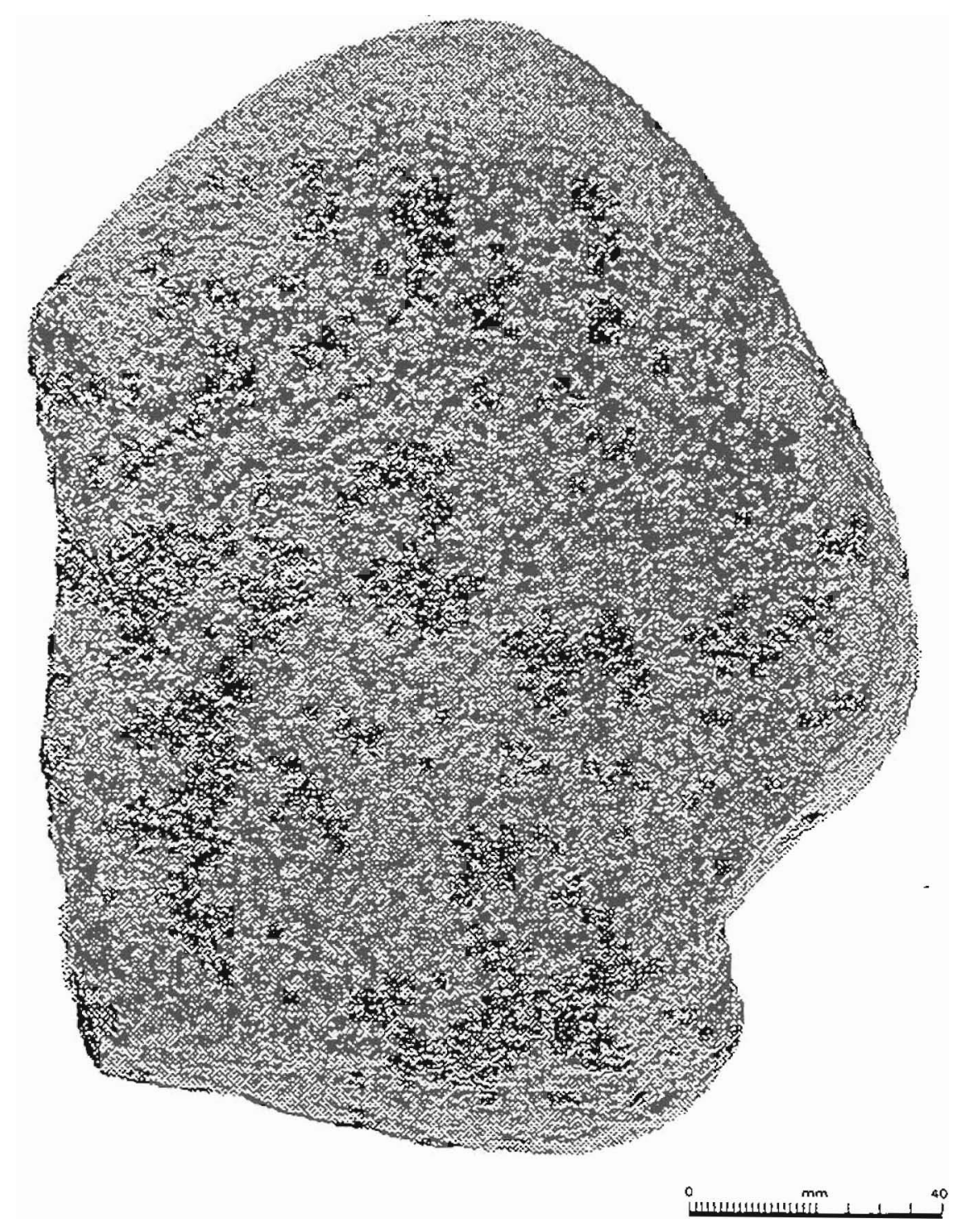

Figure 14. Ground stone recovered in Backhoe Trench 2. 
specimen collected in Trench 2 . The fragment is ground on one surface only but is pecked both to shape the artifact and roughen the grinding surface. The broken specimen recovered in Test Unit 5, Level 4 has been split lengthwise and only the ground surface remains. It is convex in shape, but no edges remain intact.

\section{Hammerstones}

Two hammerstones, both small quartzite pebbles, were collected. The larger one, $5.6 \mathrm{~cm}$ in length, is heavily battered just on one end. It is oval in shape and tan in color. The smaller hammerstone, made on a gray quartzite pebble just $3.2 \mathrm{~cm}$ long and $2.6 \mathrm{~cm}$ wide, is heavily battered along one-half its circumference. The larger specimen was collected in Level 8 of TU 4 and the smaller in TU 1, Level 6.

\section{CERAMICS}

Nine ceramic sherds were collected during the test excavations. All of these are brownwares; painting and slipping are not evident on any of them. Five of these were recovered on the surface, while the other four were recovered in Level $1(n=1)$ and Level $2(n=3)$ of Test Unit 4 (Table 3). The identifications of these sherds, discussed below, were done by David G. Robinson of the Texas Archeological Research Laboratory, the University of Texas at Austin. Other information was garnered about the type differentiations from Runyon and Hedrick (1973) and Mera (1943).

Several problems arise in the further identification of these sherds beyond mere brownwares. First, given the absence of any rim sherds in the 41EP880 ceramics collection, it is difficult to distinguish the type El Paso Brown from the painted varieties El Paso Polychrome and El Paso Bichrome. One reason is that the paint on both these latter types is only present around the upper third of the complete vessel (Whalen 1978). Secondly, the primary brownwares found in the El Paso region are, for the most part, contemporaneous and are quite similar in many ways. Alma Plain can frequently be easily distinguished, but El Paso and Jornada brownwares are very similar. Jornada Brown, according to Runyon and Hedrick (1973:23), differs from El Paso Brown primarily by having a finer temper; the temper content, however, is the same.

With all.of these conditions and problems in mind, the sherds were identified as representing all three of the above-mentioned brownwares (Figure 15). Five sherds, two from the surface and three from Level 2 in TU 4, have been identified as Alma Plain. The two surface sherds (Figure 15a and 15b) are smudged on the interior. The three subsurface specimens, which fit together forming one larger sherd (Figure 15c), are not smudged. Haury (1936) originally defined the Alma Plain type. O'L aughlin(1980:154) describes the 25 specimens recovered at two of the Keystone Dam project sites which fit the Alma Plain type as "...fine sand- tempered 
brownware...[with]. ..light gray cores and surfaces which range in color from light brown to reddish brown. The surfaces... are smoothed and occasionally show polishing marks."

The only other subsurface specimen, from Level 1 in TU 4, is a Jornada Brown sherd (Figure 16a). This type, originally defined by Jennings and Neumann (1940), is described as "...[having] inclusions from large to medium in size, very light colored, opaque and usually angular. The color ranges from deep chocolate brown to reddish browns and shades of tan. As a rule there is a pronounced blackish central core of variable width" (Mera 1943:12). One of the defining characteristics is the fineness of the temper utilized, probably for easier finishingof the vessel (Runyon and Hedrick 1973:23).

Another sherd, collected on the surface of the site, is of the El Paso Brown type (Figure 16b). The last two sherds, also from the surface, are probably of this type as well (Figure 16c and 16d). Runyon and Hedrick (1973) describe El Paso Brown as having the same temper content as Jomada Brown but with a coarser grain. The temper on all three of the sherds, though to different degrees, is coarse enough that it protrudes through the surface of the specimens from the matrix.

All these types were existent prehistorically for a long period of time. All were present during the Mesilla, or Pithouse, phase, although El Paso Brown is most common in the area during this period. None would be unexpected for the region or would they be unusual during any of the primary temporal phases discussed earlier.

Table 3. Proveniences and identification of ceramics.

$\begin{array}{llll}\text { UNIT } & \text { LV. } & \text { QUANTITY } & \text { IDENTIFICATION } \\ \text { surf. } & & \mathbf{3} & \text { El Paso Brown } \\ \text { Surf. } & & \mathbf{2} & \text { Alma Plain } \\ \text { T U 4 } & 1 & 1 & \text { Jornada Brown } \\ \text { TU 4 } & \mathbf{2} & \mathbf{3} & \text { Alma Plain }\end{array}$




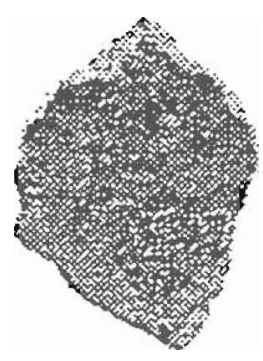

A

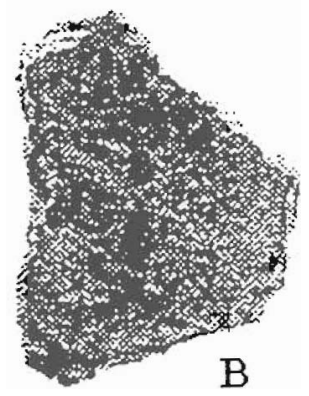

$\mathrm{B}$

0
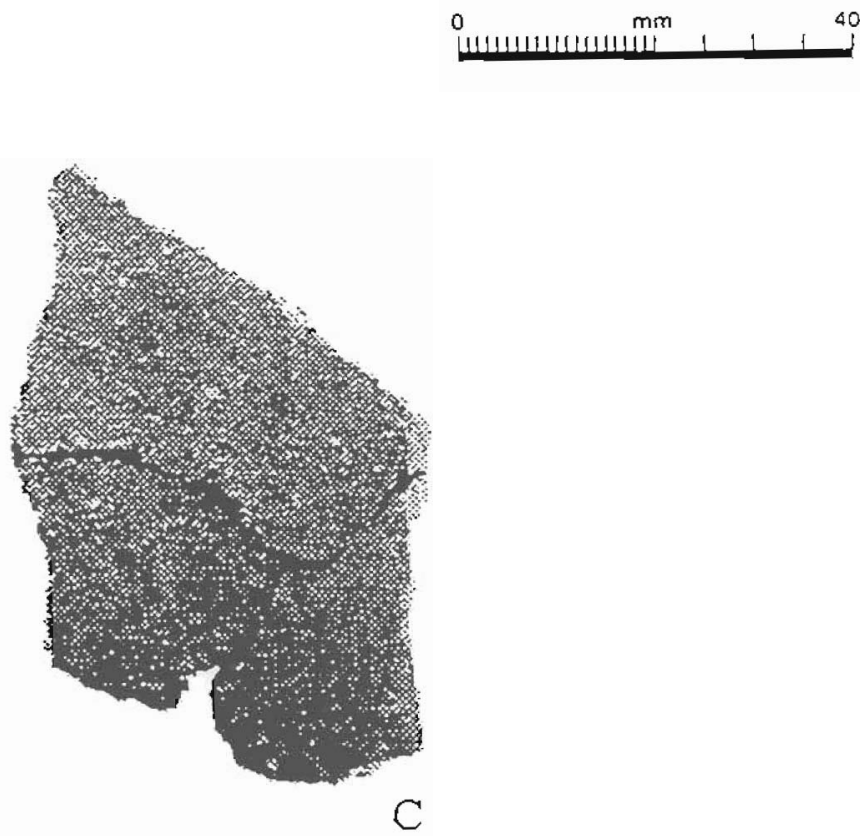

Figure 15. Alma Plain ceramics collected from both surface and subsurface contexts:

a) and b) smudged interiors of surface collected sherds;

c) exterior surface of sherd(s) collected in TU4, Lv 2. 

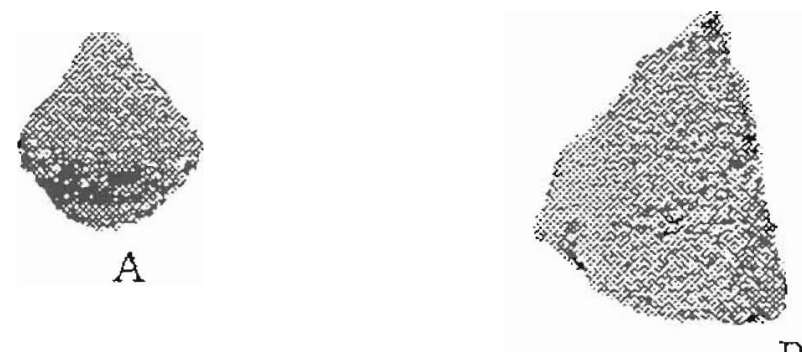

$\mathrm{B}$
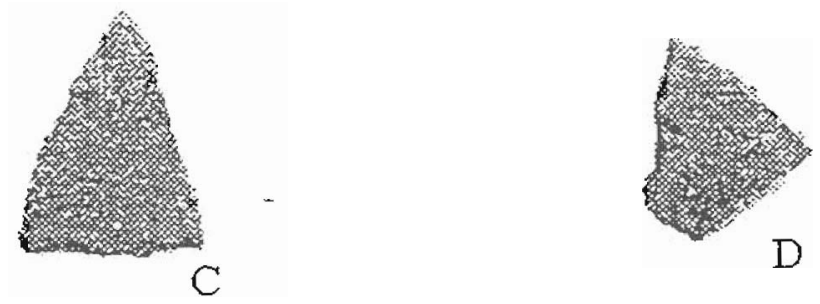

щщицищщ $\mathrm{mm}$,

Figure 16. Jornada and El Paso Brown sherds from surface and subsurface contexts:

a) Jornada Brown sherd; b) El Paso Brown sherd;

c) El Paso Brown sherd; d) El Paso Brown sherd. 


\section{DISCUSSION}

Test excavations showed primarily that, although numerous artifacts were present, the subsurface deposits at 41EP88O were very limited and likely disturbed. In only one of the test units were cultural deposits found which possibly could have reflected an intensive occupation of the site. Unfortunately, this is the same test unit which exhibited the most amount of disturbance. Historic artifacts in Test Unit 4 extended through the same levels as the majority of the prehistoric cultural debris, lending doubt to the primary context of the deposits. In other units, far less cultural debris was recovered, and no diagnostic artifacts were found in subsurface contexts.

Results of the downslope units, trenches, and shovel tests indicated that the surface distribution of artifacts was most likely the result of erosional processes, thus exaggerating the presumed site limits. In the other units upslope, other than in Test Unit 4, little cultural material was recovered. No features or subsurface concentrations of artifacts were observed. Recent disturbances were evident in nearly all subsurface exposures on the site; particularly obvious intrusions included the presence of styrofoam pieces and glass fragments in several of the shovel tests, backhoe trenches, and test units up to $0.75 \mathrm{~cm}$ below the surface. Additional disturbance, in the area where an obsidian projectile point was eroding from a cutbank along the northern rightof-way edge, was less obvious. However, when a profile was cut nearby, disturbance was again indicated by the presence of styrofoam at approximately $1.75 \mathrm{~m}$ below the surface.

The original research into site types and distributions in the area led to the expectation that this site would have been a pithouse period habitation site. The only temporally diagnostic artifacts found during the testing operations supported this to some degree. The brownware ceramic sherds recovered were identified as representing three types: Alma Plain, Jornada Brown, and El Paso Brown. All these types temporally represent extensive periods of time which, in all three cases, includes the Mesilla (pithouse) phase. None, however, are exclusive to the Mesilla phase. The occupation of 41EP880, therefore, is minimally representative of this phase and could stretch to both earlier and later times.

The small portion of the site which is within the right-of-way has been disturbed by a number of recent activities and does not accurately reflect what may still be intact in other areas of the site, particularly to the north of the right-of-way where surface evidence of features is strong. Within the right-of-way for the Artcraft Road Extension Project, there are little to no intact subsurface deposits remaining. 


\section{CONCLUSIONS AND RECOMMENDATIONS}

Site 41EP880 in northwest El Paso County was first recorded and recommended for testing during a survey of Artcraft Road from I.H. 10 to the New Mexico State Line (Browning 1992). It was further recorded and recommended for testing by a Texas Department of Transportation archaeologist later in the same year (TxDOT 1992). The testing recommendation was deemed necessary by both archeologists based on a high number of surface artifacts, including ceramic, lithic, and ground stone artifacts. In addition, the possibility of subsurface artifacts and features was suggested by the results of random shovel testing.

In January 1994, a crew of TxDOT employees returned to 41EP880 to test the site's eligibility for listing on the National Register of Historic Places. Ten test units, eight shovel tests, five backhoe trenches, and two profiles cut into the sides of sloped areas within site 41EP880 indicated a prehistoric occupation of undetermined duration and of undetermined temporal affiliation. The lack of further definition is due to a paucity of diagnostic artifacts and features at the site. Upon initial recording and background research, the site appeared to be promising in terms of buried cultural deposits; however, the extensive surface evidence for the site was determined to have been skewed by disturbance within the proposed additional 18-20 m of right-of-way; the subsurface deposits, then, are less widely distributed than the surface evidence would indicate.

Background information available for sites previously recorded along the west side of the Franklin Mountains and the eastern side of the Rio Grande suggested that 41EP880 may likely have been a Formative period habitation site. Surface evidence in the form of various brownware cenmics, scattered rock (possibly though not necessarily burned), and ground and chipped stone artifacts also were suggestive of a large habitation site.

The hand-excavated units and shovel tests turned up little which would indicate an intact subsurface extent to the site. Most units were dug either to culturally sterile deposits or to the underlying alluvial gravels. All units and shovel tests indicated a large amount of mixing of the prehistoric and historic deposits. The historic deposits are all very recent in nature and are probably the result of extensive dirt borrowing or trash dumping in the area. Three dirt roads cut through the site from Artcraft Road and run to the north. It is not known if any of these were created with the help of earth-moving equipment, but the indications are that some such equipment was utilized on the site. These indications include reverse stratigraphy in some areas where the prehistoric cultural debris is underlain by historic trash (glass and styrofoam pieces). This type of disturbance was further indicated by the profile of Backhoe Trench 2, the only trench in which intact subsurface deposits were indicated.

Though some artifacts were found during testing that suggested time periods for the occupation of the site (i.e. ceramics), these artifacts were also generic in that brownware ceramics were present in the area prehistorically for over 1,000 years. No other artifacts identified from the site could further define the temporal affiliation of the occupation.

Given the extensive surface distribution of artifacts both within and outside the proposed right-of-way, the site was undoubtedly Quite large. The cultural integrity of these deposits, within the right-of-way, is thought to have been lost, however. As a result, further investigations are not deemednecessary at site $41 \mathrm{EP} 88 \mathrm{O}$ within the proposed right-of-way for the extension of Artcraft 
Road from the New Mexico State Line to Interstate Highway 10 in El Paso County. The site is not considered eligible for listing on the National Register of Historic Places. Any original features have been destroyed over the years, some from the original disturbance of road constructionby the county or more recently by borrowing and dumping activities on the site area. 


\section{REFERENCES CITED}

Black, Stephen L. and A. Joachim McGraw

1985 The Panther Springs Creek site: Cultural change and continuity within the Upper Salado Creek Watershed, south-central Texas. Archaeological Survey Report 100. Center for Archaeological Research, The University of Texas at San Antonio.

Brook, Vernon Ralph

1966 They didn't barter to fill the larder. The Artifact 4(3):1-15. El Paso Archaeological Society, El Paso.

1968 A Folsom and other related points found near El Paso, Texas. The Artifact 6(3):11-15. El Paso Archaeological Society, El Paso.

Browning, Cody Bill

1992 Class II cultural resources study for the proposed Artcraft and Sunland Park Drive Ports-of-Entry Preferred Alternatives, Dona Ana County, New Mexico, and El Paso County, Texas. Submitted by Human Systems Research, Inc., Tularosa, New Mexico to Marron, Taschek, and Knight, Inc., Corrales, New Mexico.

Carmichael, David

1983 Archaeological survey of the Southern Tularosa Basin, New Mexico. Prepared for the Environmental Office, Directorate of Facilities Engineering, Fort Bliss Air Defense Center, Fort Bliss, Texas.

1985 Archeological excavations at two prehistoric campsites near Keystone Dam, El Paso, Texas. University Museum Occasional Papers No. 14. New Mexico State University, Las Cruces.

Fenneman, Nevin M.

1931 Physiography of the western United States. McGraw-Hill Book Company, Inc. New York.

Fields, Ross C. and Jeffrey S. Girard

1983 Investigations at site 32 (41EP325), Keystone Dam Project: A multicomponent archaeological site in western El Paso County, Texas. Reports of Investigations, Number 21. Prewitt and Associates, Inc. Austin.

Gerald, Rex E.

n.d. Report on an archaeological survey of five local protection project dams and associated drainage and diversion channels in northwest El Paso, Texas. Manuscript on file, El Paso Centennial Museum, The University of Texas at El Paso. 
Haury, E. W.

1936 Some southwestern pottery types, Series IV. Medallion Papers No. XIX, pp. 2834. Gila Pueblo. Globe, Arizona.

Holliday, Vance T.

1983 Appendix A: Geological investigations. In Investigations at site 32 (41EP325),

Keystone Dam Project: A multicomponent archaeological site in western

El Paso County, Texas, by Ross C. Fields and Jeffrey S. Girard, pp. 249-263.

Reports of Investigations, Number 21. Prewitt and Associates, Inc. Austin.

Jaco, Hubert B.

1971 Soil suvey of El Paso County, Texas. United States Department of Agriculture, Soil Conservation Service in cooperation with Texas Agricultural Experiment Station. Washington, D.C.

Jennings J.D. and George Neumann

1940 A variation of southwestern Pueblo Culture. Technical Series Bulletin No. 10. Laboratory of Anthropology. Santa Fe, New Mexico.

Johnson, LeRoy, Jr.

1991 Early Archaic life at the Sleeper archaeological site, 41BC65, of the Texas Hill Country, Blanco County, Texas. Publications in Archeology Report 39. Highway Design Division, Texas State Department of Highways and Public Transportation. Austin.

Jones, Courtenay J.

1985 Appendix III: Glossary of lithic terms. In The Panther Springs Creek site: Cultural change and continuity within the Upper Salado Creek Watershed, SouthCentral Texas, by Stephen L. Black and A. Joachim McGraw, pp. 387-389. Archaeological Survey Report, No. 100. Center for Archaeological Research, The University of Texas at San Antonio.

Kaufman, Barbara

1984 The Vista Hills site: Eight thousand years at the edge of the Hueco Bolson. Cultural Resource Management Division Report 563, New Mexico State University, Las Cruces.

Lehmer, Donald J.

1948 The Jornada Branch of the Mogollon. Social Science Bulletin 17. University of Arizona, Tucson.

Lovejoy, Earl M. P. 
1980 El Paso's geological past. Science Series, Number 7. Texas Western Press, The University of Texas at El Paso.

Mera, H.P.

1943 An outline of ceramic developments in southern and southeastern New Mexico. Technical Series Bulletin No. 11. Laboratory of Anthropology. Santa Fe, New Mexico.

O'Laughlin, Thomas C.

1977 Excavations at the Sandy Bone site. Awanyu 5(2):11-42. Archaeological Society of New Mexico, Las Cruces.

1980 The Keystone Dam site and other Archaic and Formative sites in northwest El Paso, Texas. Publications in Anthropology No. 8. El Paso Centennial Museum, The University of Texas at El Paso.

Quimby, Byron and V.R. Brook

1967 A Folsom site near El Paso, Texas. The Artifact 5(4):31-47. El Paso Archaeological Society.

Runyon, John W. and John A. Hedrick

1973 Pottery types of the SWFAS area. Transactions of the Eighth Regional Archeological Symposium for Southeastern New Mexico and Western Texas, pp. 19-45. Lea County Archeological Society.

Sellards, E.H., W.S. Adkins, and F.B. Plummer

1932 The geology of Texas, Volume I: Stratigraphy. The University of Texas Bulletin, No. 3232. Austin.

Texas Department of Transportation

1992 Artcraft Road Extension from New Mexico State Line to Interstate Highway 10. Archaeological Resources Survey Report on file, Environmental Affairs Division, Texas Department of Transportation, Austin.

Whalen, Michael E.

1978 Settlement patterns of the western Hueco Bolson. Publications in Anthropology No. 6. El Paso Centennial Museum, The University of Texas at El Paso.

1985 Comments on Wiseman's proposed changes in some of the Ceramic Period taxonomic sequences of the Jornada Branch of the Mogollon. In Proceedings of the Third Jornada Mogollon Conference, edited by Michael S. Foster and Thomas C. O'Laughlin. The Artifact 23(1-2):19-22. El Paso Archaeological Society, El Paso. 